\author{
نقش آبيارى تكميلى و كاربرد زئوليت بر رشد و عملكرد عدس \\ (Lens culinaris Medik)

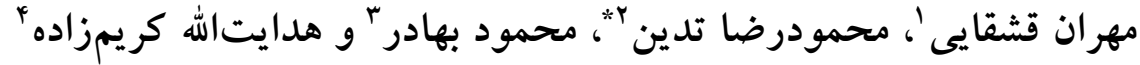 \\ (تاريخ دريافت: 1400/T/19؛ تاريخ يذيرش: 1400/0/9)
}

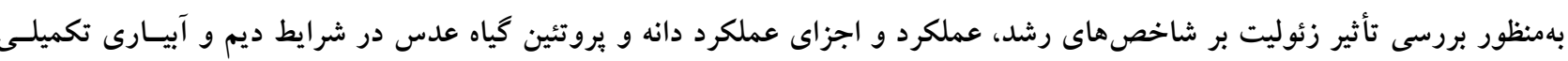

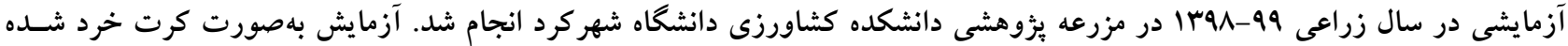

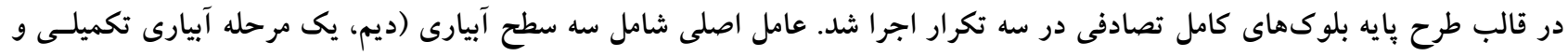

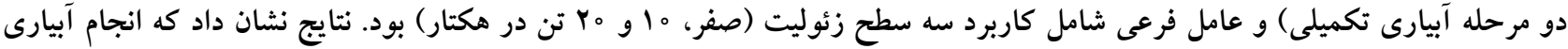

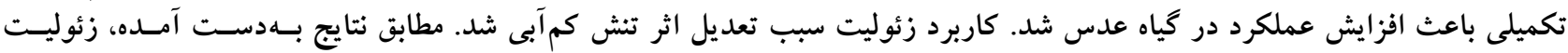

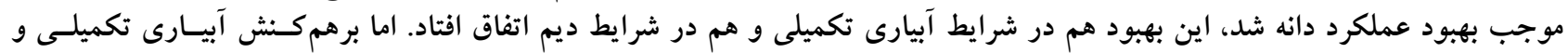

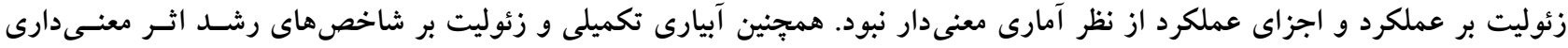

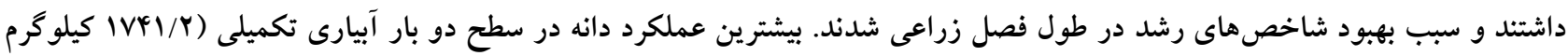

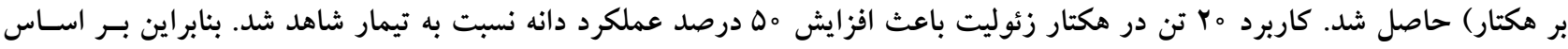

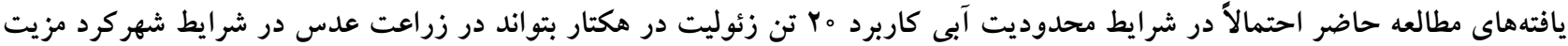
نسبى داشته باشد.

وازههاى كليدى: تنش خشكى، حبوبات، شاخصهاى رشد، شرايط ديم

ا، ب و r. بهترتيب دانشجو كارشناسى ارشد، استاد و دانشجوى سابق دكترى گروه زراعت، دانشكده كشاوزىى، دانشكاه شهركرد، شهركرد، ايران

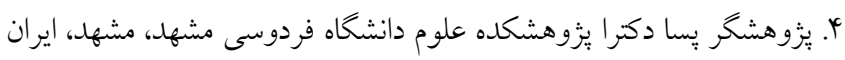
mrtadayon@yahoo.com : مسئول مكاتبات: بست الكترونيكى : 
ميزان Or درصد نسبت به شرايط بدون آبيارى افزايش داد. همخجنين

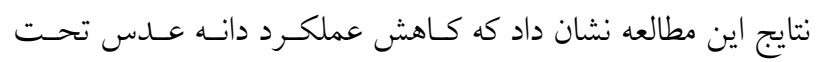

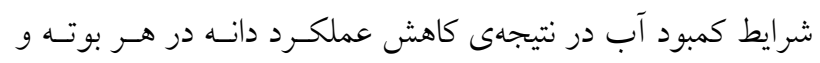

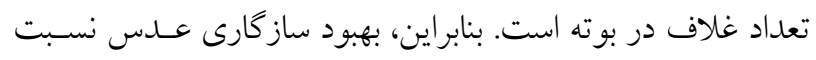

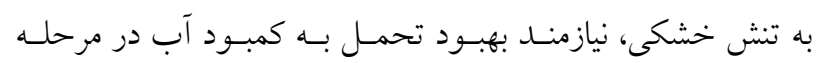

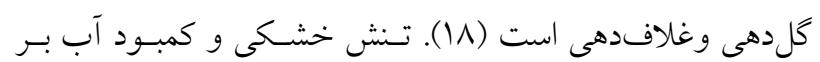

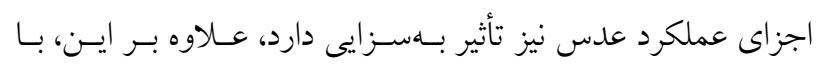

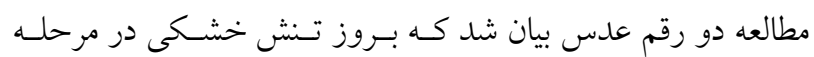

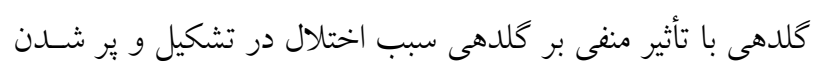

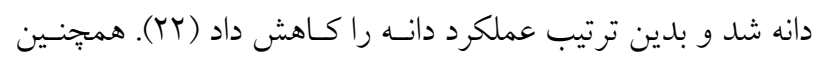

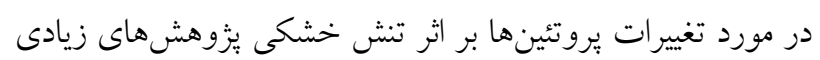

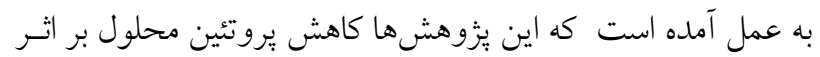

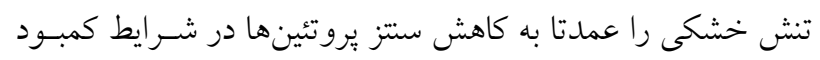

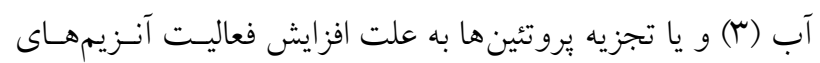

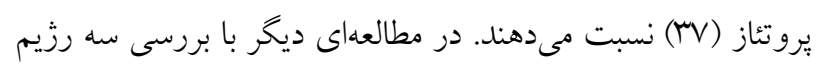

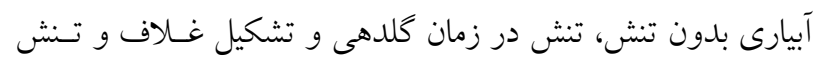

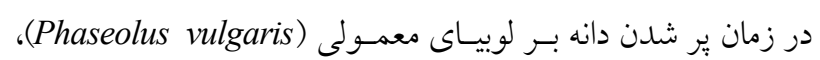

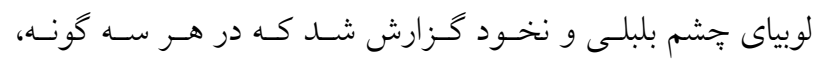

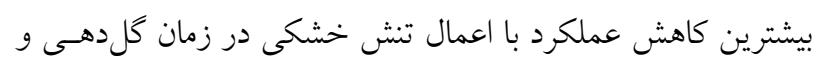

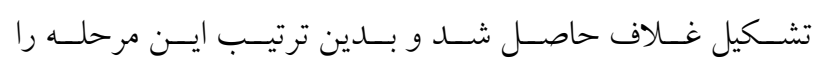

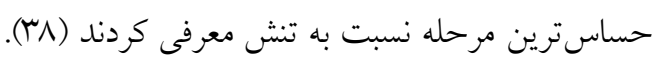

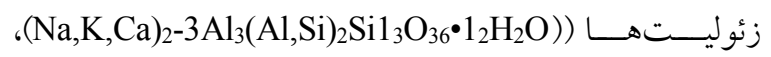

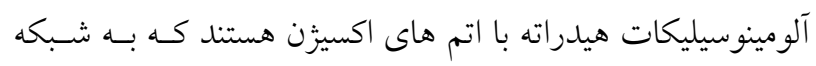

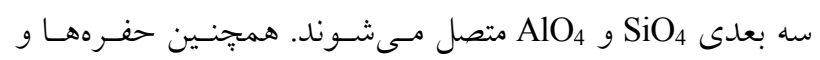

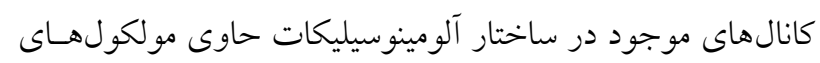
آب با كاتيونهايى هستند كه بار منفى ناشسى از جـايخزينى مانى

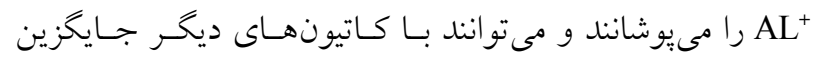

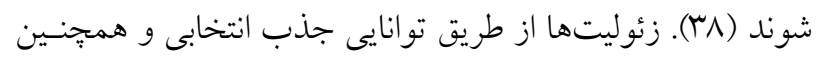

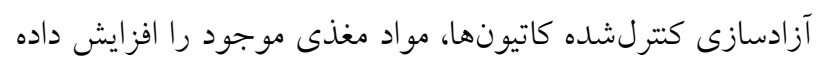

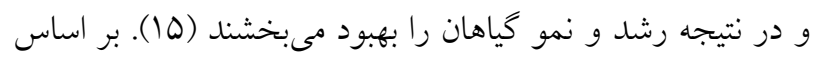

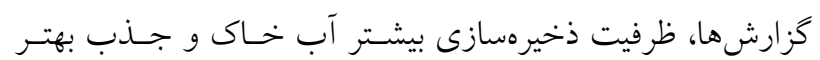

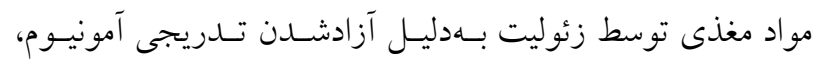

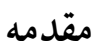

مشكل كمآبى و بروز تنش خشكى و استـفاده بهينـه از آب در ايسران،

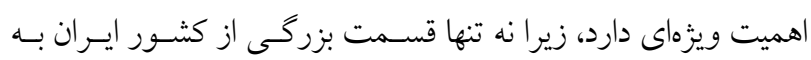

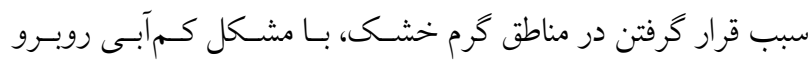

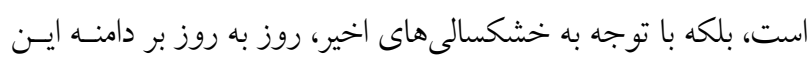

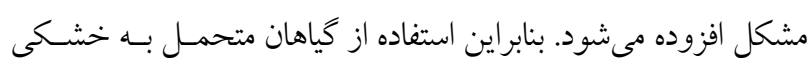

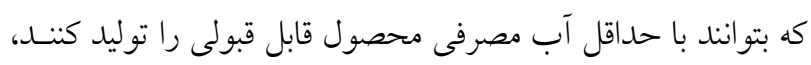

ضرورى به نظر مىرسد (Y) (1). عدس (Lens culinaris Medik) يكى از قديمىترين كياهـان

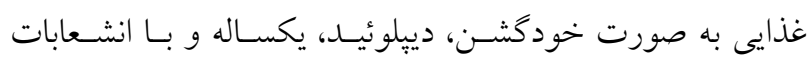

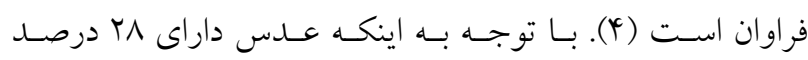

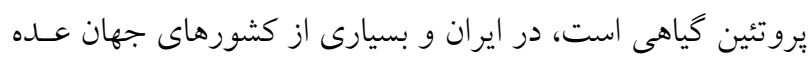

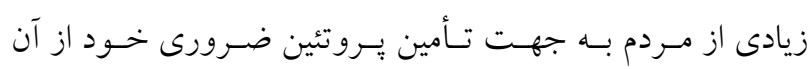

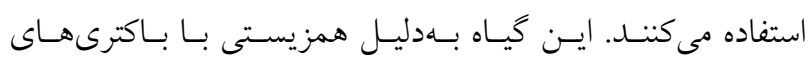
تثبيت كننده نيتروزن هوا نقش مؤثرى در حاصسلخيزى خهـاك دارد

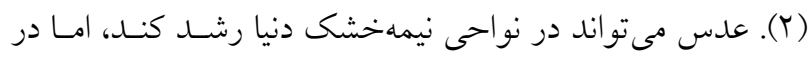

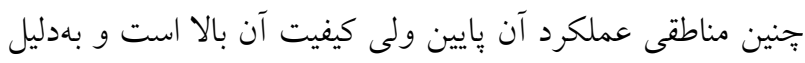

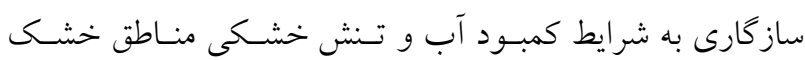

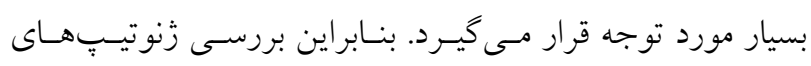

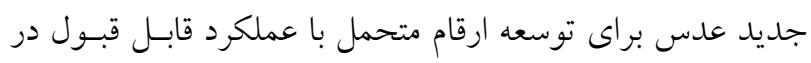

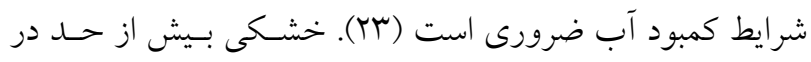

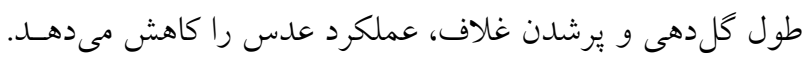
تنش خشكى در مرحله كُلدهى باعث كاهش طول دوروه كل علدهى،

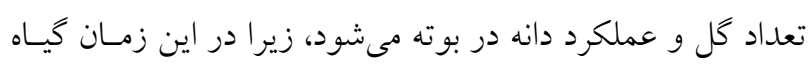

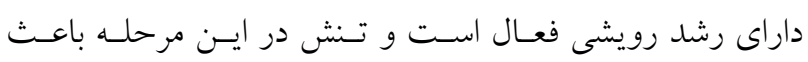

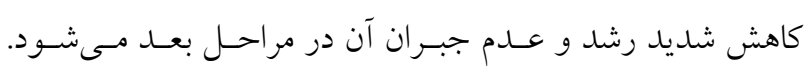

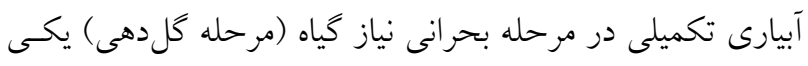

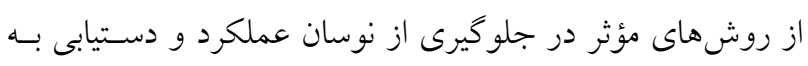

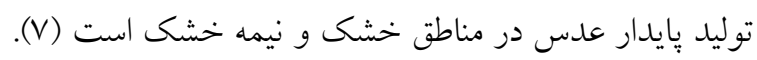

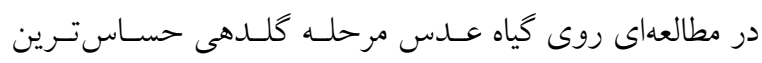

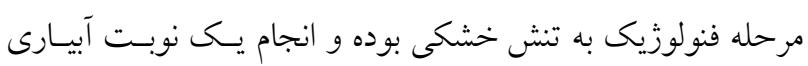

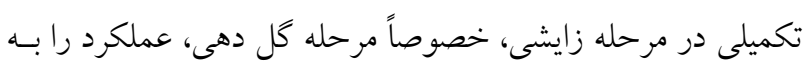




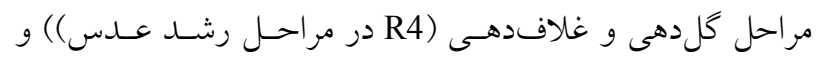

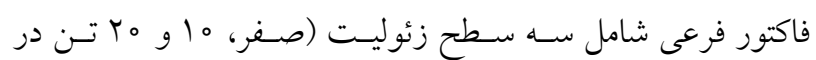

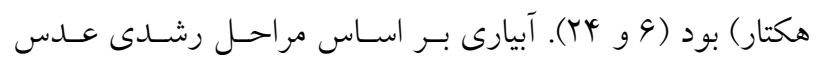

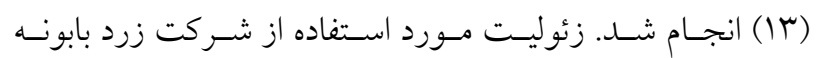

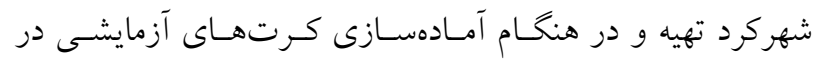
اختيار تيمارهاى مورد نظر قرار خرفت. در اين مطالعه جهت آمادهسازى بستر كشت، زمين با كاور آهن

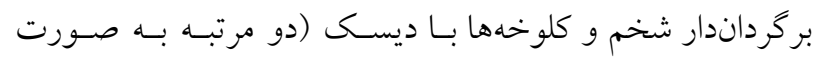
عمود بر هم) خرد شده و سبس با استفاده از ماله اقدام به تسطيح

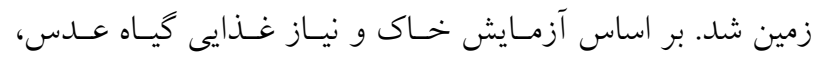

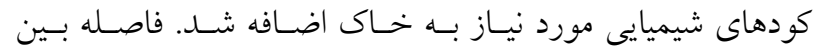
كرتها يك متر و بين بلوكها دو متر در نظـر كرفتـه شـــ. ابعـاد

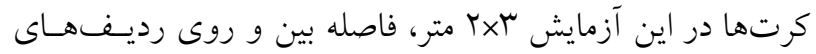

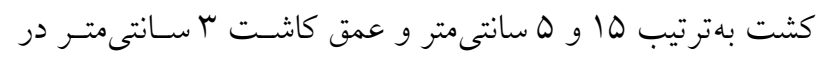

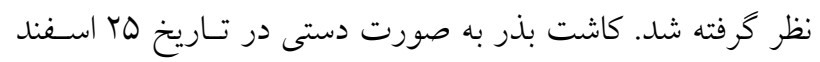

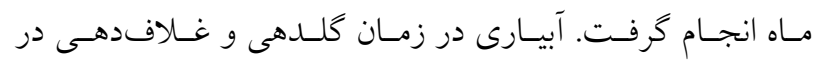
تيمارهاى مربوط انجام شد و شرايط ديم براى سطح شاهد درن درنظر

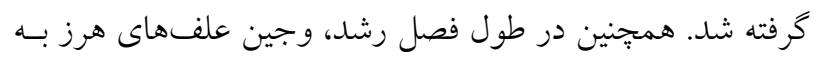
صورت دستى انجام كرفت.

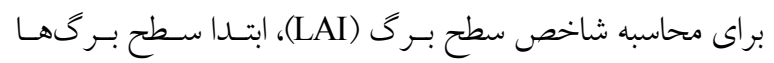

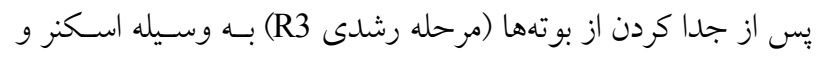

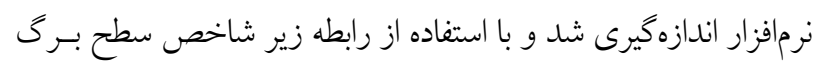

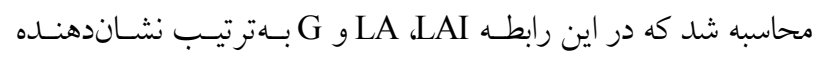

شاخص سطح برگ، مساحت برگ و مساحت زمين هستند (سب). $\mathrm{LAI}=\mathrm{LA} / \mathrm{G}$

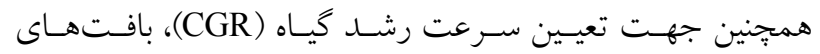

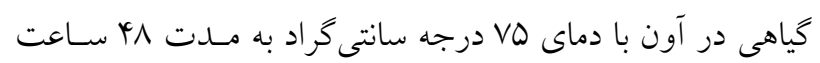
قرار گرفت و بِ از خشكشدن، توسط ترازوى ديجيتال تـوزين شده و سرعت رشد كياه از طريق مشتق گيرى از معادله روند رشد

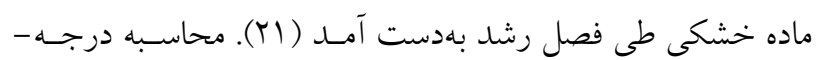

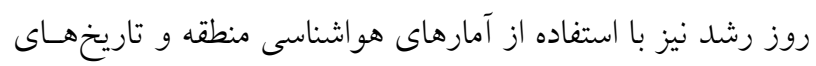

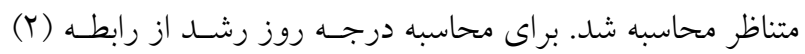

ظرفيت تبادل كاتيونى بـالا، بِيــارى سـاختارى و تخلخـل زيـاد

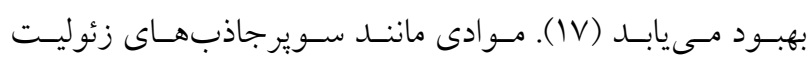

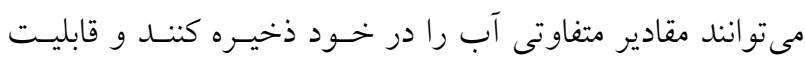

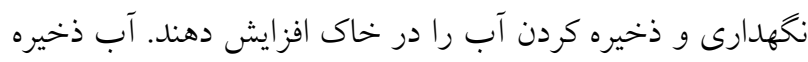

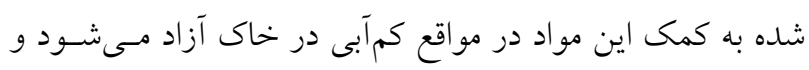

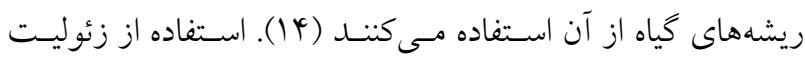

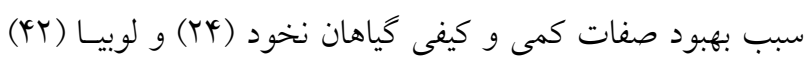

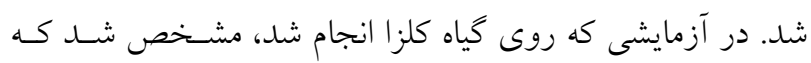

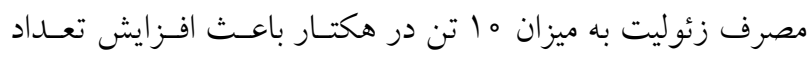

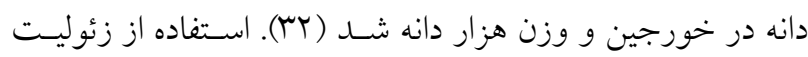

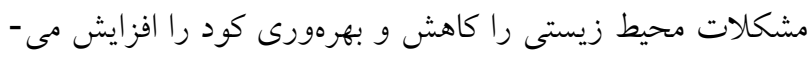
دهد (Y) و همجنـين باعـث افـزايش فراهمى نيتـروزن، فسـفر،

كلسيم و منيزيم در خاك مى شود (1). با توجه به تهديد روزافزون كم آبى در ايران، بـهـويـرَه اسـتان

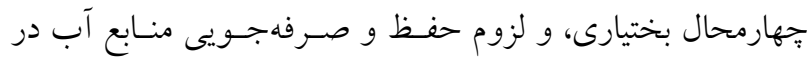

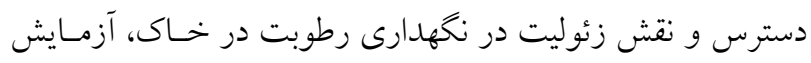

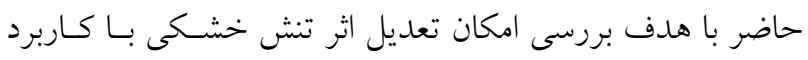

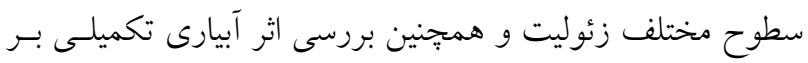

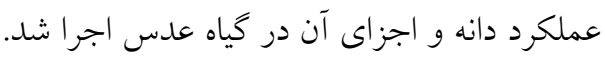

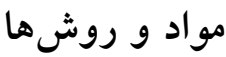

اين آزمايش در مزرعه يزوهشى دانشكاه شهركرد واقع در كيلومتر

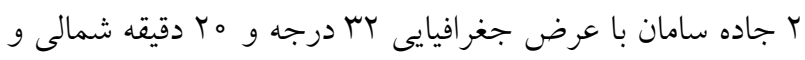

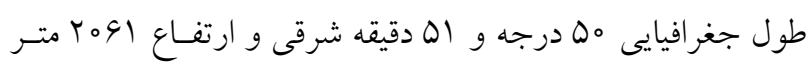

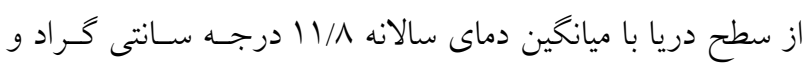

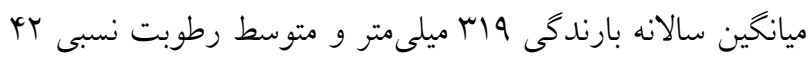

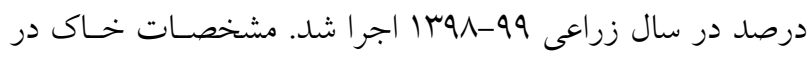

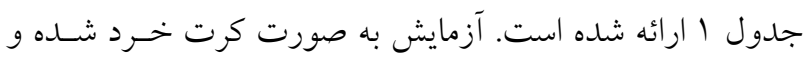

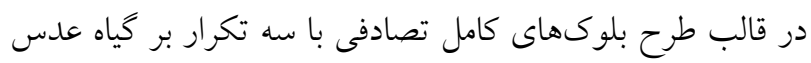

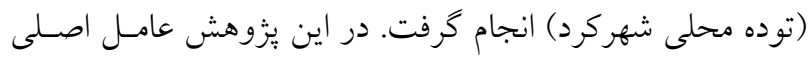

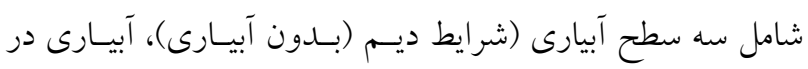

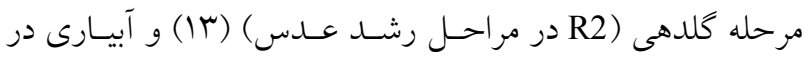


جدول ا. خصوصيات فيزيكى و شيميايى خاك محل آزمايش

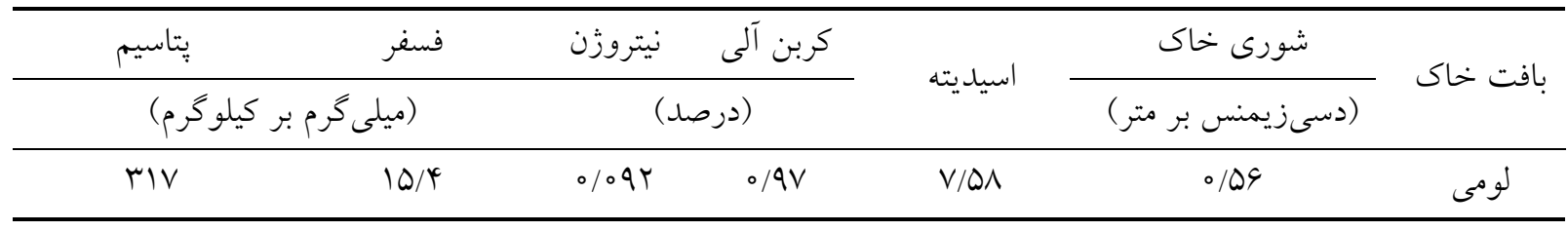

قيف مسدودكننده شيشهاى رسوب داده شد. هر مرتبه، قيف دوبار

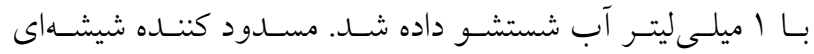
جايكزين شده و ها ميلى ليتر سود ه4 درصد در قيف ريخته شد.

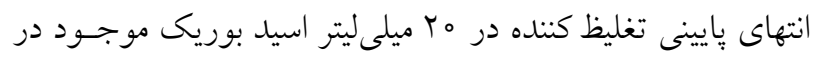

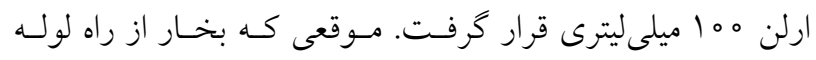

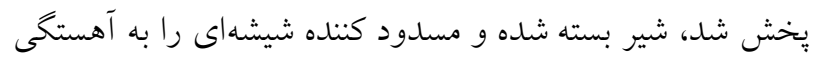

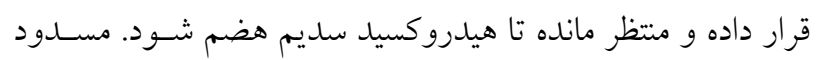

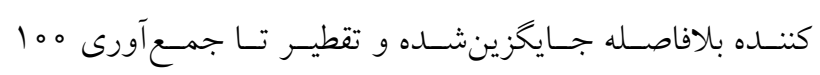

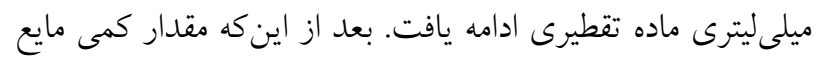
تقطير شد، از انتهاى متراكمتر روى سطح اسيد بوريـك بـ بـالا آمــد.

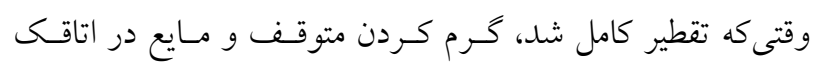

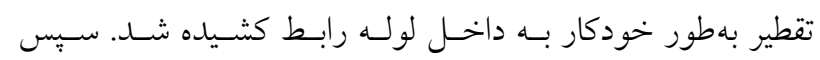

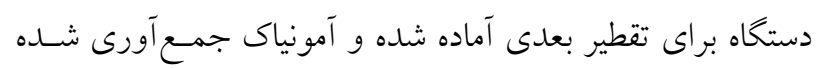

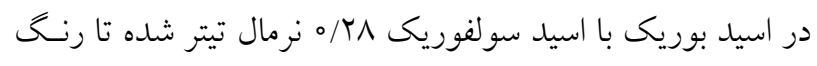

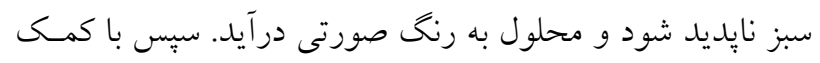
رابطه زير ميزان نيتروزن دانه محاسبه شد:

$$
\mathrm{N}_{\text {content }}(\%)=(\mathrm{T}-\mathrm{B}) \times 10 \times \mathrm{N}(1.4 / \mathrm{W})
$$

تيتراسيون نمونه (ميلى ليتـر اسسيد اسـتاندارد)، B= تيتراسـيون شاهد (ميلى ليتر اسـيد اسـتاندارد)، N= نرماليتـه اسـيد اسـتاندارد،

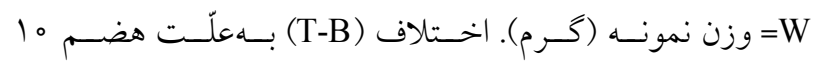
ميلى ليتر بايــ در ه ا ضـرب مسىشـود. در مرحلـه بعـد، درصـد نيتروزن بهدست آمله در عدد ه/ آ ضرب شد و درصد يـروتئين بهدست آمد (9) (9) (9)

جهت اندازهيرى زيست توده و عملكـــد دانسه يسس از حسـف اثرات حاشيهاى، بوتهها از سطح يـك مترمربـع از مركـز هـر كـرت برداشت شدند. سبس جهت ختى كردن اثر رطوبـت در تيمارهـاى Vo مختلف، نمونههاى برداشت شده از هر كـرت در آون بـا دمـاى

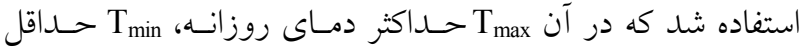

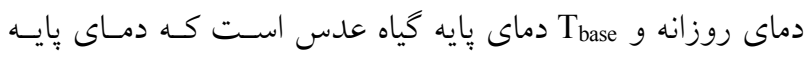

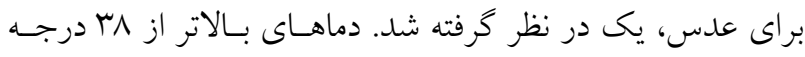
سانتى گراد را نيز مب درجه سانتى كراد منظور شد (YY).

GDD $=\sum\left(\mathrm{T}_{\max }+\mathrm{T}_{\min }\right) / 2-\mathrm{T}_{\text {base }}$

جهت تعيين اجزاى عملكرد دانه از كل بوتههاى برداشـتشـــه

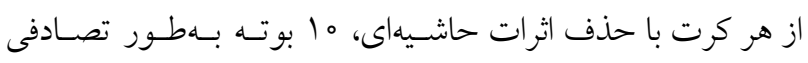

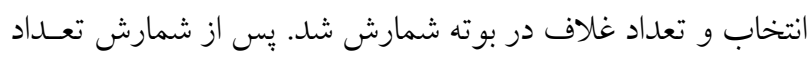

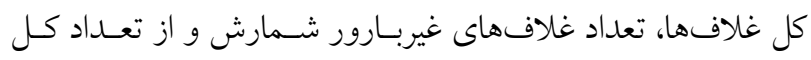

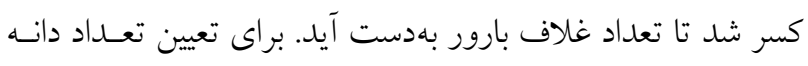

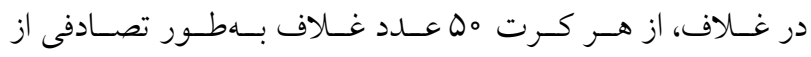

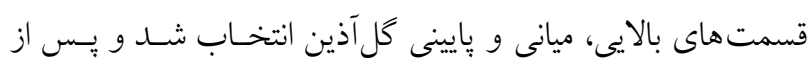

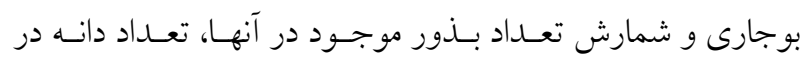
غلاف مشخص شد. وزن هـزار دانـه نيـز بـهـ روش تصـادفى و بـر

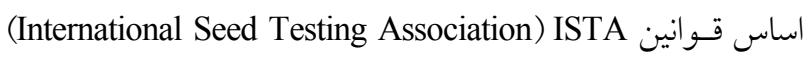
تعيين شد. درصد يُروتئين دانه از روش ميكرو كجلدال و عملكـرد يروتئين دانه نيز از ضرب درصد پـروتئين دانسه در عملكـرد دانهـ

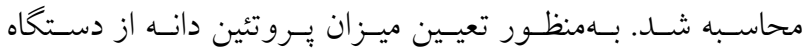

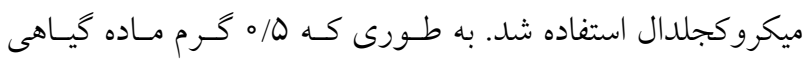

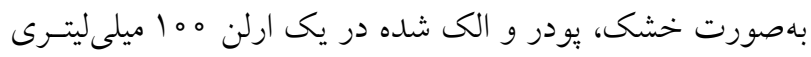
ميكرو كجلدال خشك ريخته و مقدارى كاتاليست و ه 1 ميلسليتـر

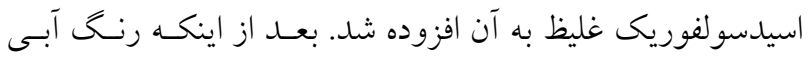

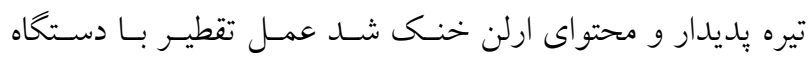

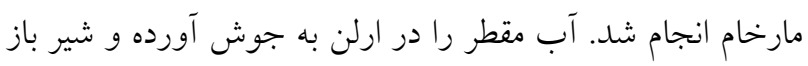

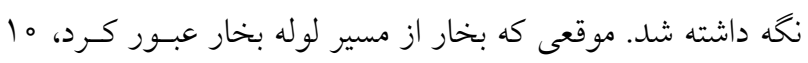

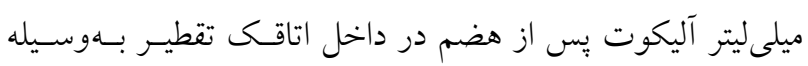



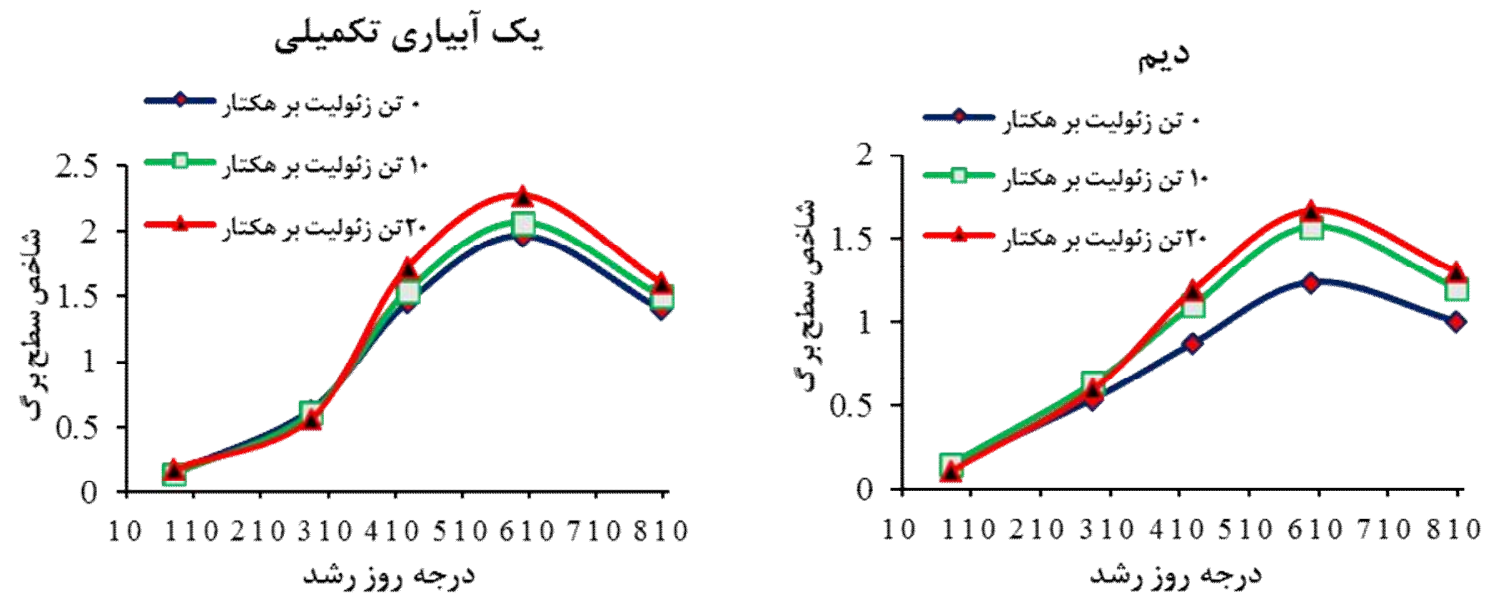

دو آبيارى تكميلى

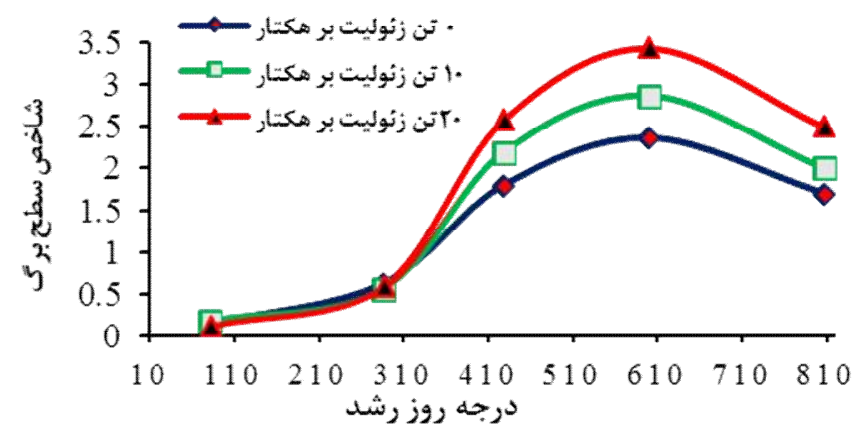

شكل ا. تغييرات روند شاخص سطح برى در طى فصل رشد در شرايط آبيارى تكميلى و زئوليت در گياه عدس

بيروى كرد (شكل (1). در اين آزمـايش شـاخص سـطح بـرى بـا

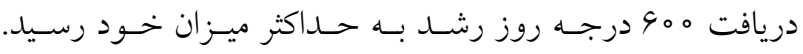
بيشترين شـاخص سـطح بـرى (T/O/O) در تيمـار دو بـار آبيـارى تكميلى و مr تن زئوليت در هكتـار حاصـل شــ، از طرفى نيـز كمترين شاخص سطح برى (I/T) نيـز در تيمـار بــون مصـرف زئوليت و در شرايط ديم بهدست آمد كه مىتوان كفـت انجـام دو

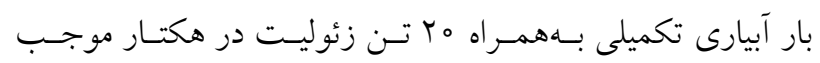
افزايش شاخص سطح برى به ميزان Y/AT برابر نسبت به شـرايط ديم و عدم مصرف زئوليت شــ (شـكل (). بـا توجـهـ بـه نتـايج مىتوان كفت كه كاهش تعداد آبيارى باعث كاهش حداكثر ميـزان سطح برك شد و با مصـرف زئوليـت از شـــت كـاهش حـــاكثر سطح برى كاسته شد، بهطورى كه در شرايط ديم، يك بار آبيارى و دو بار آبيـارى تكميلسى و مصـرف مب تـن زئوليـت در هكتـار
درجه سانتى گر اد بهمدت VY ساعت قرار گرفتنــ تــا رطوبـت دانـه براى همه تيمارها به صورت يكسـان باشــ و در نهايست وزن كـل زيست توده و عملكرد دانه اندازهگيرى شد. براى محاسـبه شـاخص برداشت نيز از نسبت وزن عملكرد دانه به زيست توده استفاده شد. در نهايت دادهها يس از اطمينان از توزيع نرمال آنها با استفاده

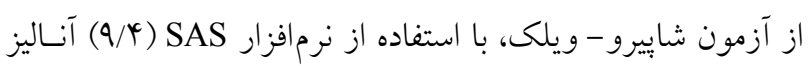
واريانس شدند (ه广). براى مقايسه ميانخينها نيـز آزمـون حـداقل اختلاف معنى دار در سطح احتمال ينج درصد استفاده شد.

\section{نتايج و بحث} شاخص سطح برى همانطور كه نتايج نشان مىدهد، روند تغييـرات شـاخص سـطح برى در تمامى تيمارهاى آبيارى و زئوليـت از مـدل سـيخموئيدى 


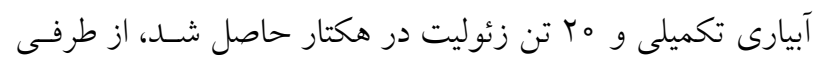

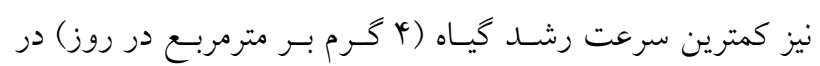

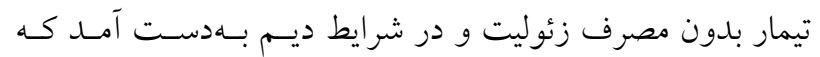

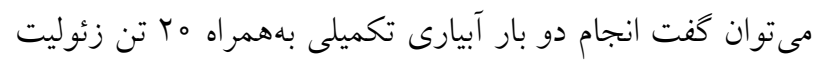

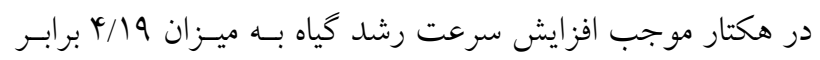

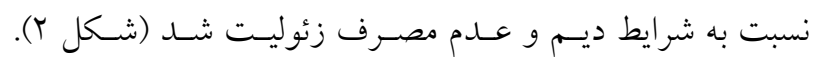

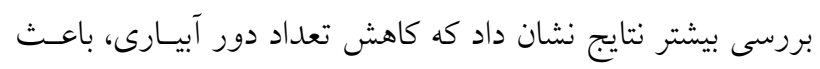

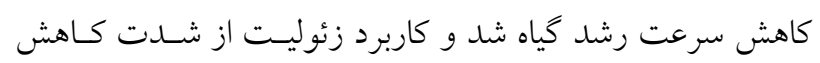

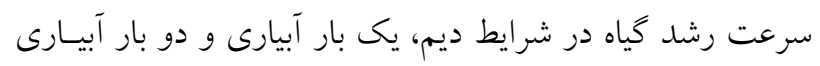
تكميلى كاست بهطورى كه با مصرف ه ب تـن زئوليـت در هكتـار

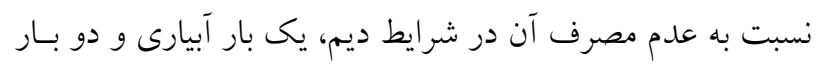

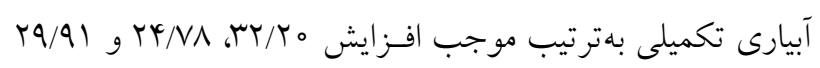

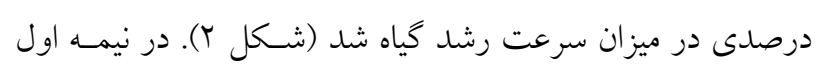

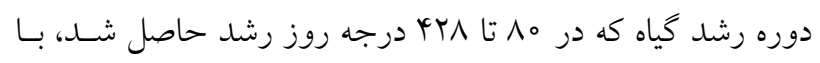

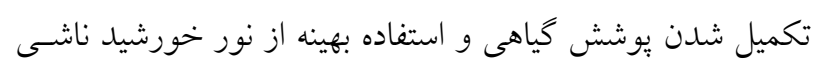

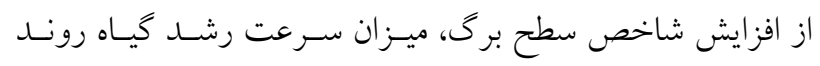

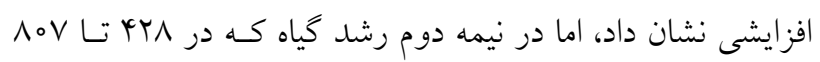

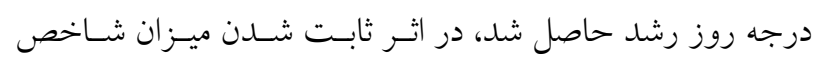

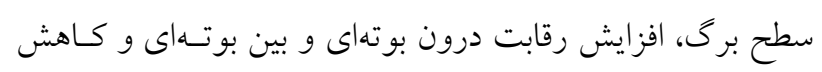

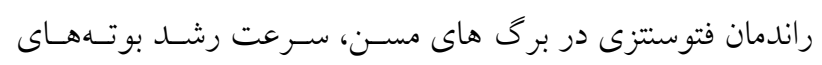

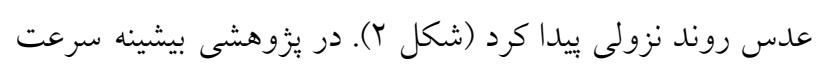

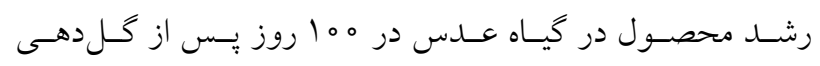

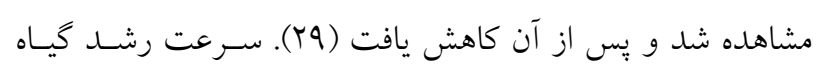

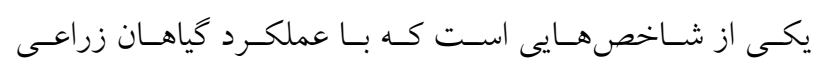

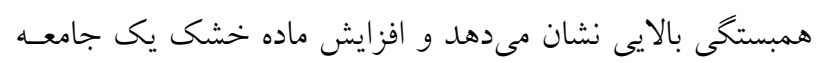

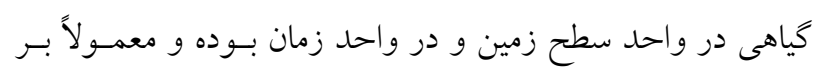

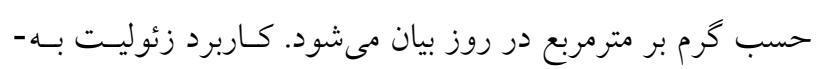

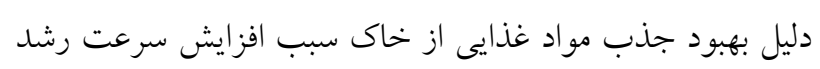
محصول مىشود.

\section{تعداد كل غلاف در بوته}

نتايج نشان داد كه اثر آبيـارى تكميلـى و زئوليـت بـر تعـداد كـل

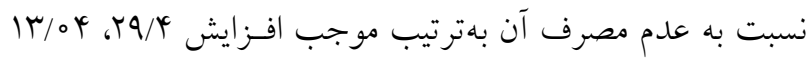

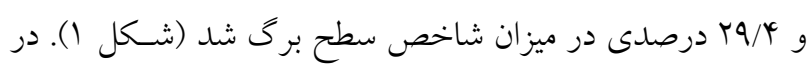

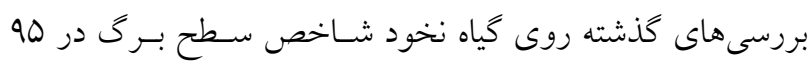

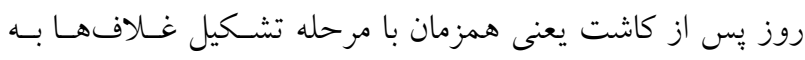

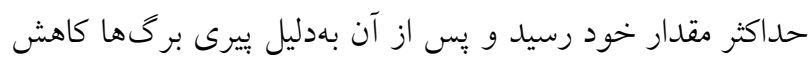

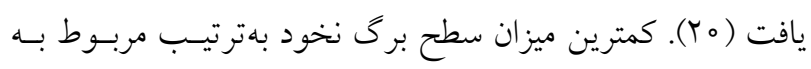

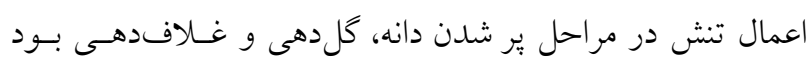

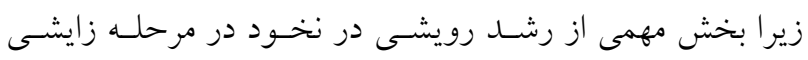

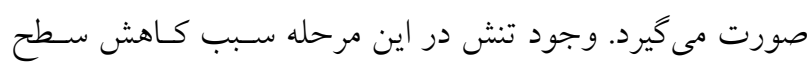

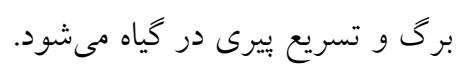

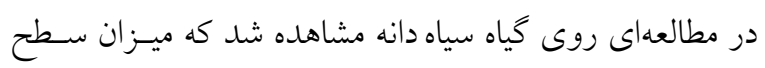

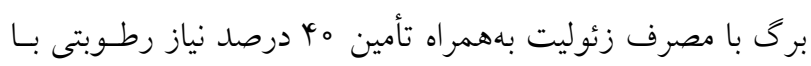

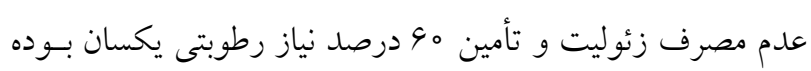

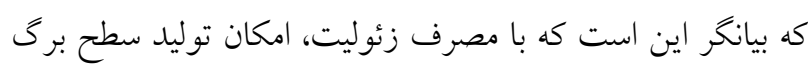

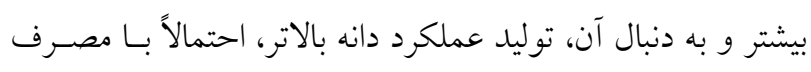

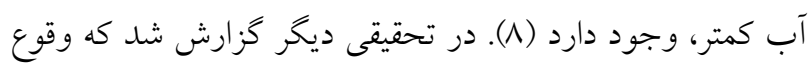

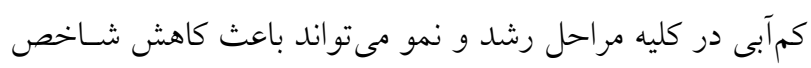

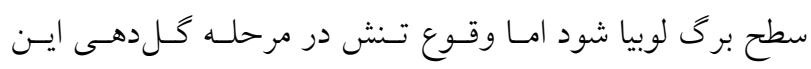

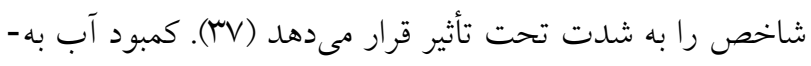

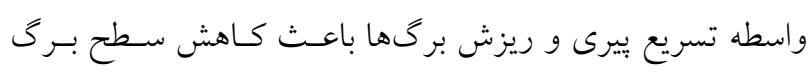

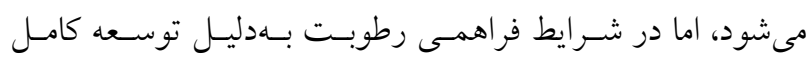

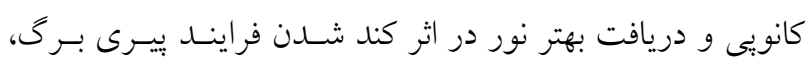

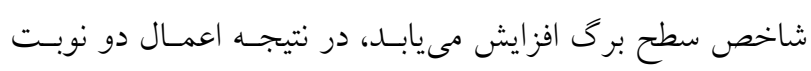
آبيارى در مرحله كَلدهى عدس و تأمين رطوبت مورد نيـاز كيـاه

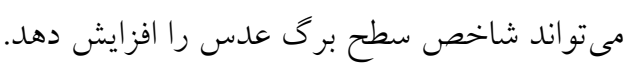

$$
\text { سرعت رشد گياه }
$$

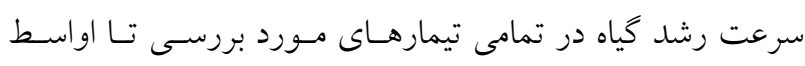

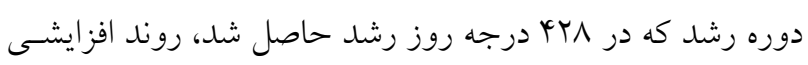

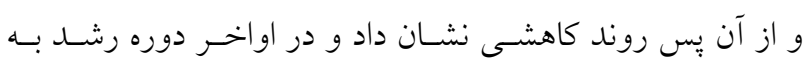
سمت صفر ميـل كـرد (شـكل Y). نتسايج نشـان داد كـه بيشـترين

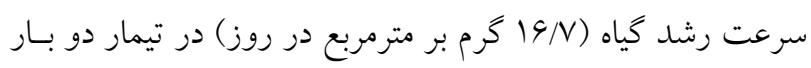


يكى آبيارى تكميلى

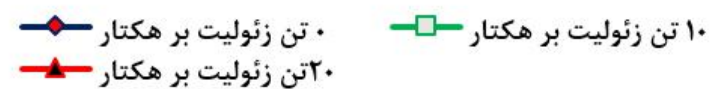

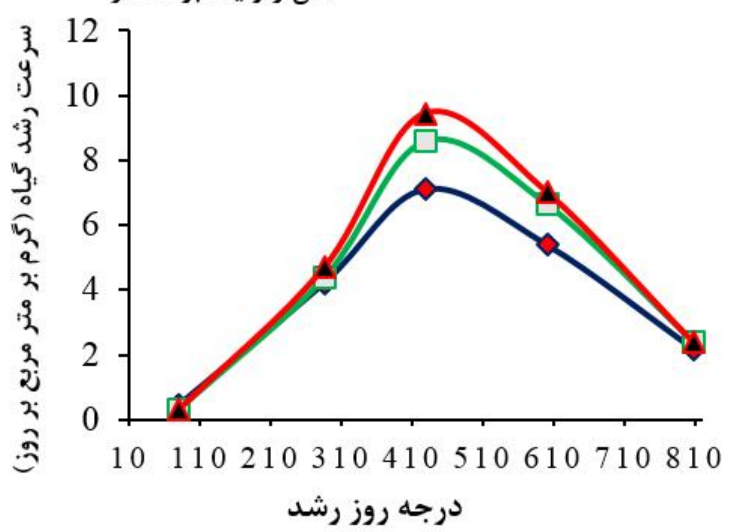

ديم
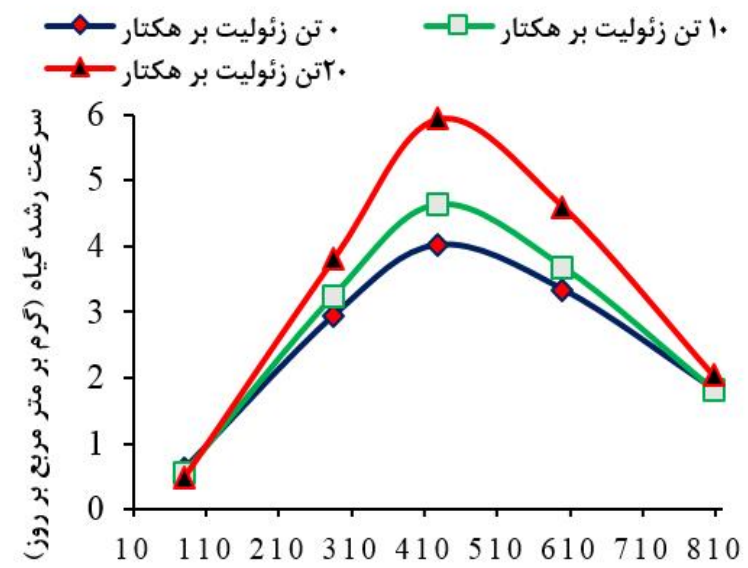

درجه روز رشد

دو آبيارى تكميلى

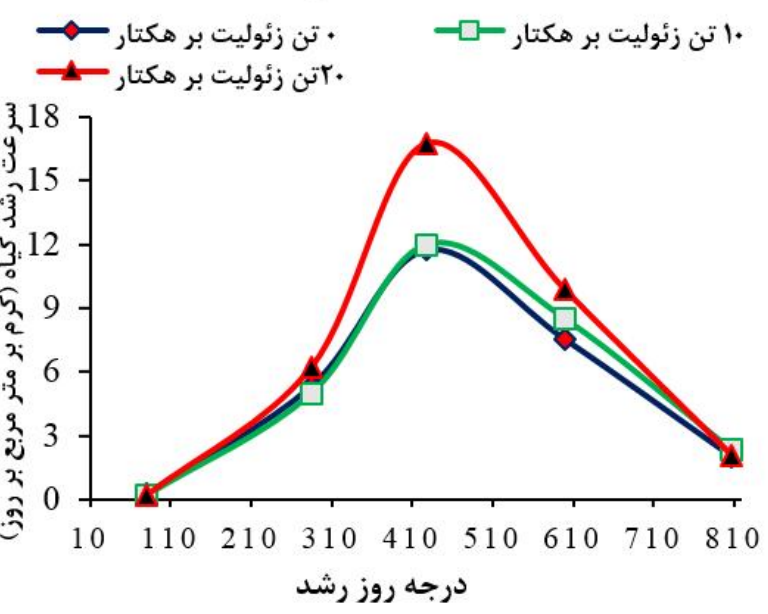

شكل r. تغييرات روند سرعت رشد گياه در طى فصل رشد در شرايط كاربرد آبيارى تكميلى و زئوليت در گياه عدس

همجنين مصرف مب تن زئوليت در هكتار، بيشترين تعداد غـلاف

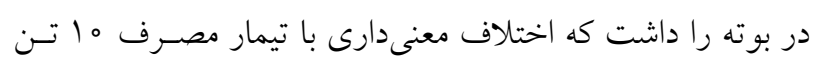

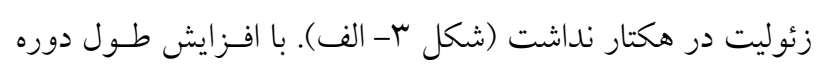
رشد زايشى تعداد كل غلاف در عدس افزايش مسى يابـــ. بـهنظـر

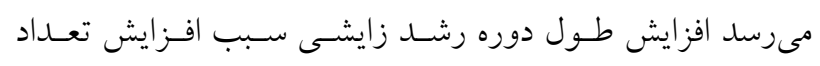

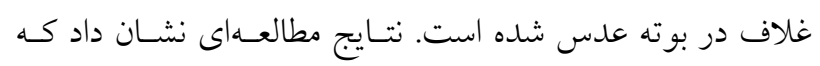

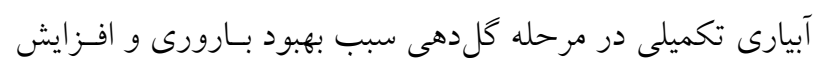

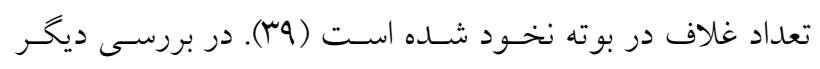

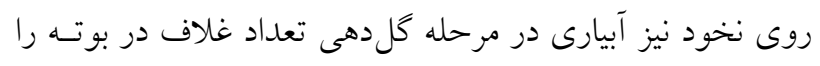

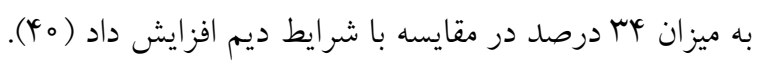

غلاف در بوته در سطح احتمال يكى درصد معنى دار شد، امـا اثـر

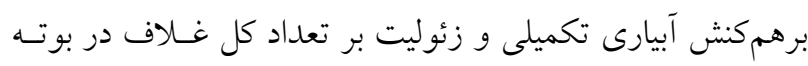

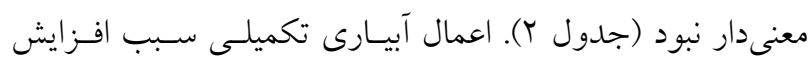

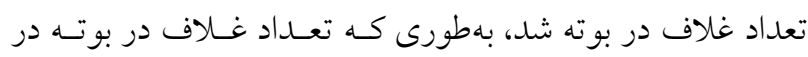

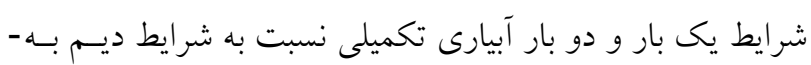

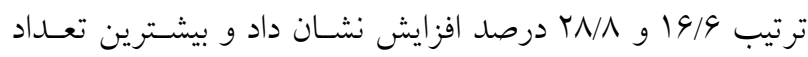

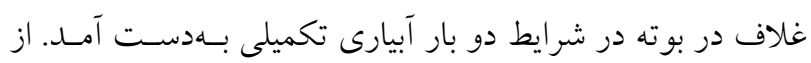

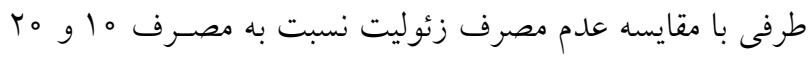

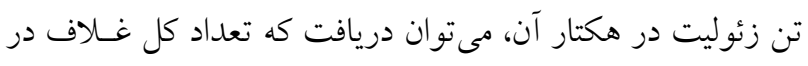

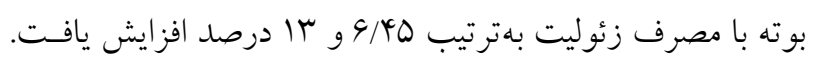


جدول r. آناليز واريانس عملكرد دانه، اجزاى عملكرد دانه، عملكرد ماده خشك، شاخص برداشت و عملكرد بروتئين عدس در تيمارهاى آبيارى تكميلى و زئوليت

\begin{tabular}{|c|c|c|c|c|c|c|c|c|c|}
\hline $\begin{array}{l}\frac{9}{3} \\
\sqrt{3} \\
3 \\
3 \\
3 \\
3 \\
3\end{array}$ & $\begin{array}{c}3 \\
3 \\
3 \\
\frac{1}{3} \\
: 3\end{array}$ & $\begin{array}{l}\frac{9}{3} \\
\sqrt{2} \\
2 \\
3 \\
3 \\
0 \\
1 \\
3 \\
3\end{array}$ & $\begin{array}{l}\frac{y}{3} \\
\frac{3}{2} \\
\frac{1}{3} \\
\frac{n}{3}\end{array}$ & $\begin{array}{l}\stackrel{2}{3} \\
\frac{3}{3} \\
\frac{2}{3}\end{array}$ & 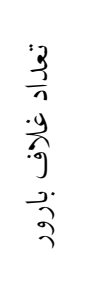 & $\begin{array}{l}3 \\
\frac{3}{2} \\
\frac{1}{3} \\
3 \\
3 \\
.9 \\
.9\end{array}$ & $\begin{array}{l}\frac{3}{2} \\
3 \\
y \\
\cdot y \\
\cdot \hat{9} \\
3 \\
3 \\
3 \\
3\end{array}$ & $\frac{\hat{\jmath}}{\frac{\hat{y}}{\hat{y}}}$ & $\begin{array}{l}3 \\
2 \\
\vdots 3 \\
3 \\
3\end{array}$ \\
\hline $19 \Lambda^{* *}$ & $0 / 01^{\mathrm{ns}}$ & raYkns & 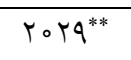 & $q^{\mathrm{ns}}$ & $99^{* *}$ & $\circ / 1^{* *}$ & $\circ / Q^{n s}$ & r & بلوى \\
\hline $911^{* *}$ & $\circ /^{* *}$ & $\left.9 \Delta \Delta \varphi^{*}\right)^{* *}$ & MOLY** & $r 90^{* *}$ & $V r q^{* *}$ & $\circ / \mu^{* * *}$ & kro** & r & آبيارى \\
\hline 0 & $\circ / 0 \circ Y$ & 1499 & VT & V & 1 & $0 / 001$ & 10 & 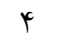 & خطاى الف \\
\hline $110^{* *}$ & $0 / 01^{* *}$ & $\mid M T Y \Lambda^{* *}$ & $4909^{* *}$ & $\varphi \wedge^{* *}$ & $111^{* * *}$ & $\circ / \mu^{* * *}$ & $q r^{* *}$ & r & زئوليت \\
\hline$\wedge^{\mathrm{ns}}$ & $\circ /\left.00\right|^{\text {ns }}$ & $\mid Y V Y^{\mathrm{ns}}$ & rypus & $\mu_{\mathrm{ns}}$ & $\mu^{n s}$ & $\% / 0 \circ r^{\mathrm{ns}}$ & $\varphi^{n s}$ & r & آبيارى \\
\hline V & o/oor & $q \mu q$ & $1 \circ V$ & r & r & $0 / 001$ & $\varphi / 0$ & Ir & خطا \\
\hline 10 & 0 & $\wedge$ & 9 & r & V & 0 & 0 & \multicolumn{2}{|c|}{ ضريب تغييرات } \\
\hline
\end{tabular}

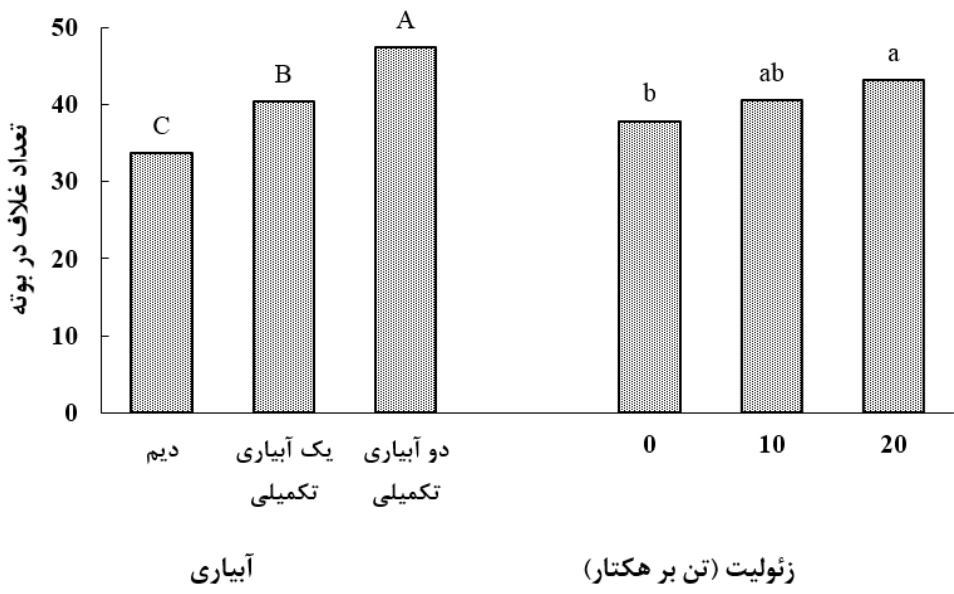

(الف)

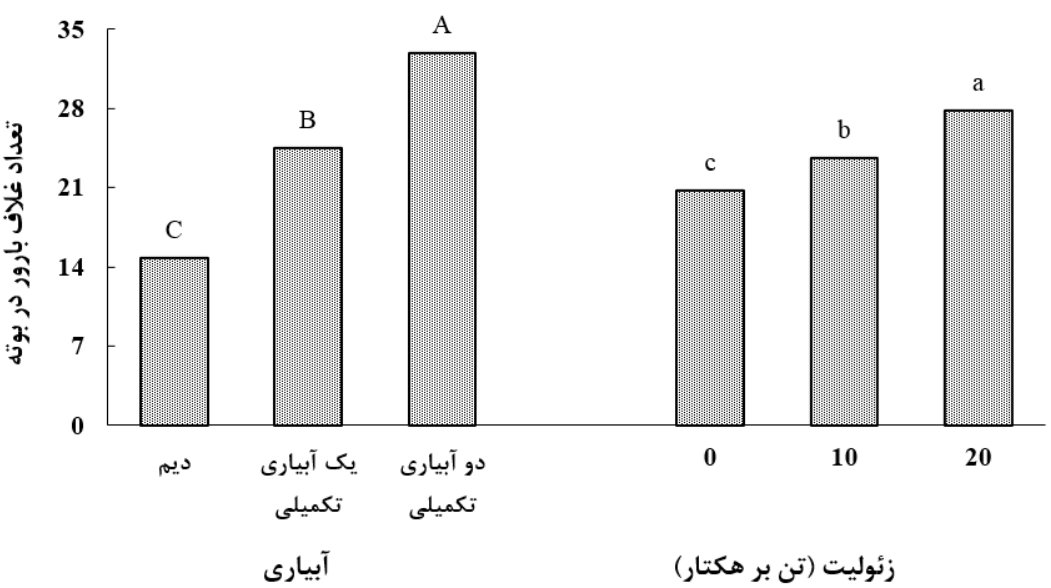

(ب)

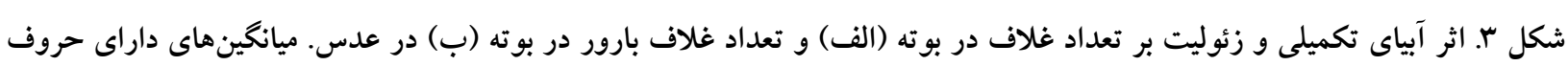

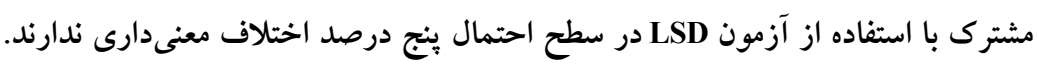


عدم مصرف آن اختلاف معنىدارى را از نظر تعداد دانه در غلاف

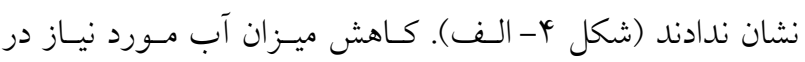

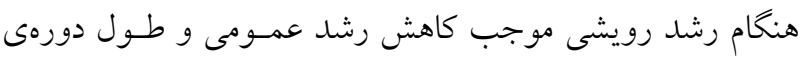
رشد كياه و تشكيل تعداد كمتر دانه در غلاف شده اسـت. كمبـود

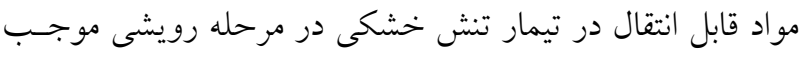

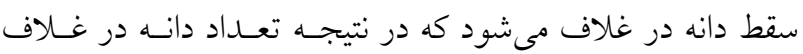

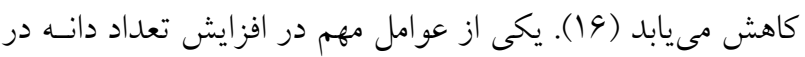

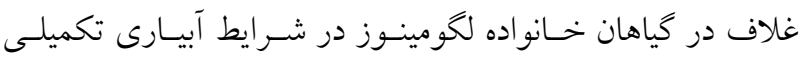

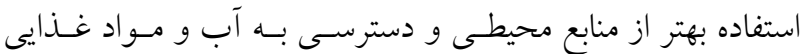
است كه روند مادهسازى را بهبود بخشيده و باعث افزايش تعسداد بالاترى از كلها و دانههاى بوتهها مىشود. فراهمسى رطوبـت بـهـ ميزان كافى و آبيارى تكميلى در مرحله كل دهى نتخـود در بهـبـود بارورى غلافها و افزايش تعداد غلاف در بوته تـأثير معنسدارى داشت (r). كل دهى و غلافدهـى مر احـل بحر انسى نيـاز آبسى در

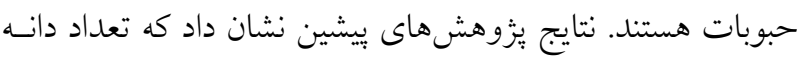

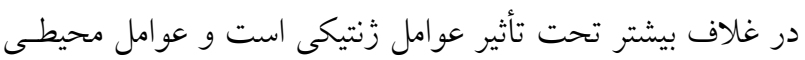

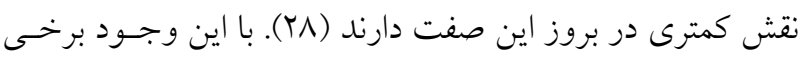

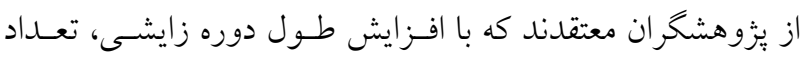
دانه در غلاف نيز افزايش مىيابد (بم).

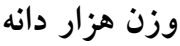

بر اساس نتايج مندرج در جدول تجزيسه واريـانس، اثـرات سـاده آبيارى تكميلى و مصرف زئوليت اثر معنىدارى بر وزن هزار دانهـ

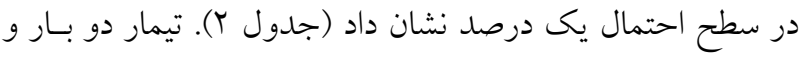

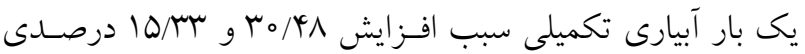

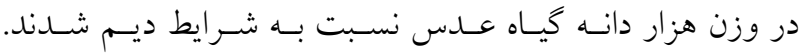

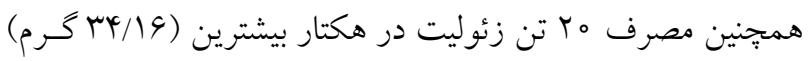
وزن هزار دانه را دارا بود كه نسبت به مصرف ها التسن در هكتـار

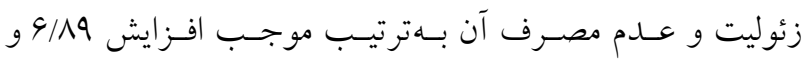

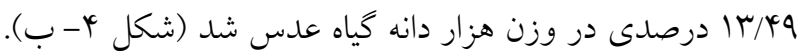

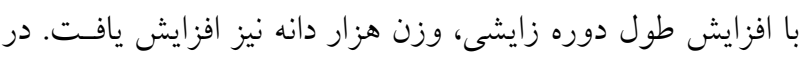
صورت كمبود رطوبت در دسترس در مرحلـهى زايشى دانسهــا
تعداد غلاف بارور نتايج جدول تجزيه واريانس نشان داد كه اثرات اصسلى آبيـارى و

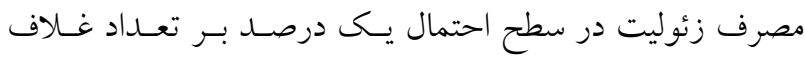

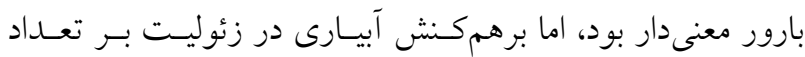

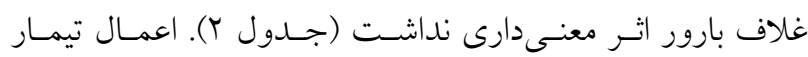

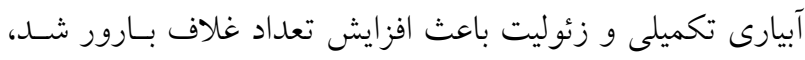

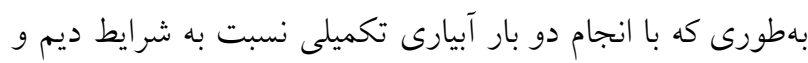

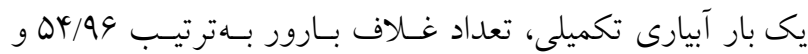

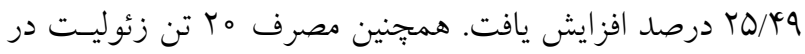
هكتار نسبت به عدم مصرف و مصرف ما اتن زئوليت در هكتـار

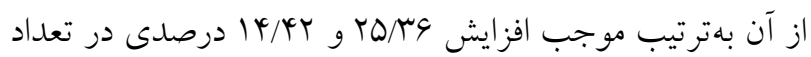
غلاف بارور در بوته شد. در شرايط آبيارى، بيشترين تعداد غلاف

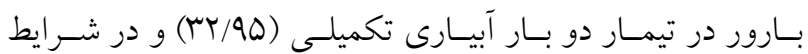
كـاربرد زئوليـت در شـرايط كـاربرد مب تــن زئوليـت در هكتـار (TV/AV)

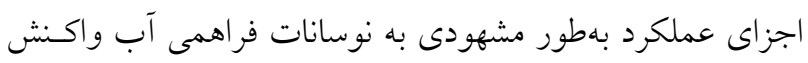

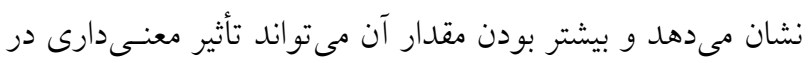

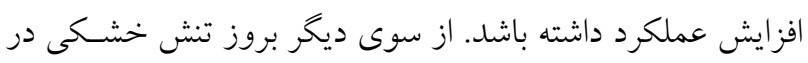

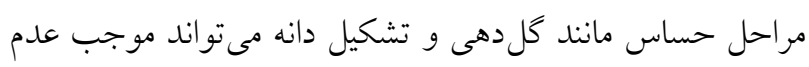

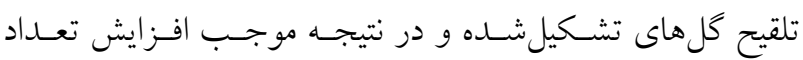
غلافهاى نابارور و كاهش غلافهاى بارور شود.

\section{تعداد دانه در غلاف}

بر اساس نتايج مندرج در جدول r، اثثر آبيارى تكميلى و مصـرف

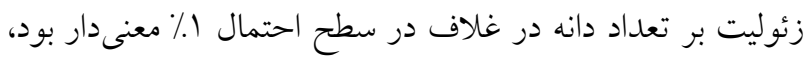

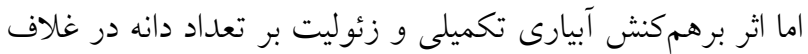

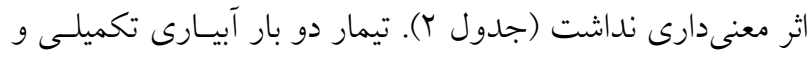

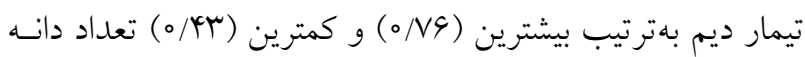

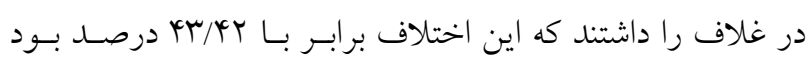

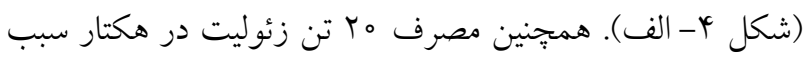

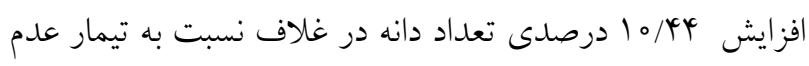
مصرف زئوليت شد. از طرفى مصرف ها اتن زئوليت در هكتار و 

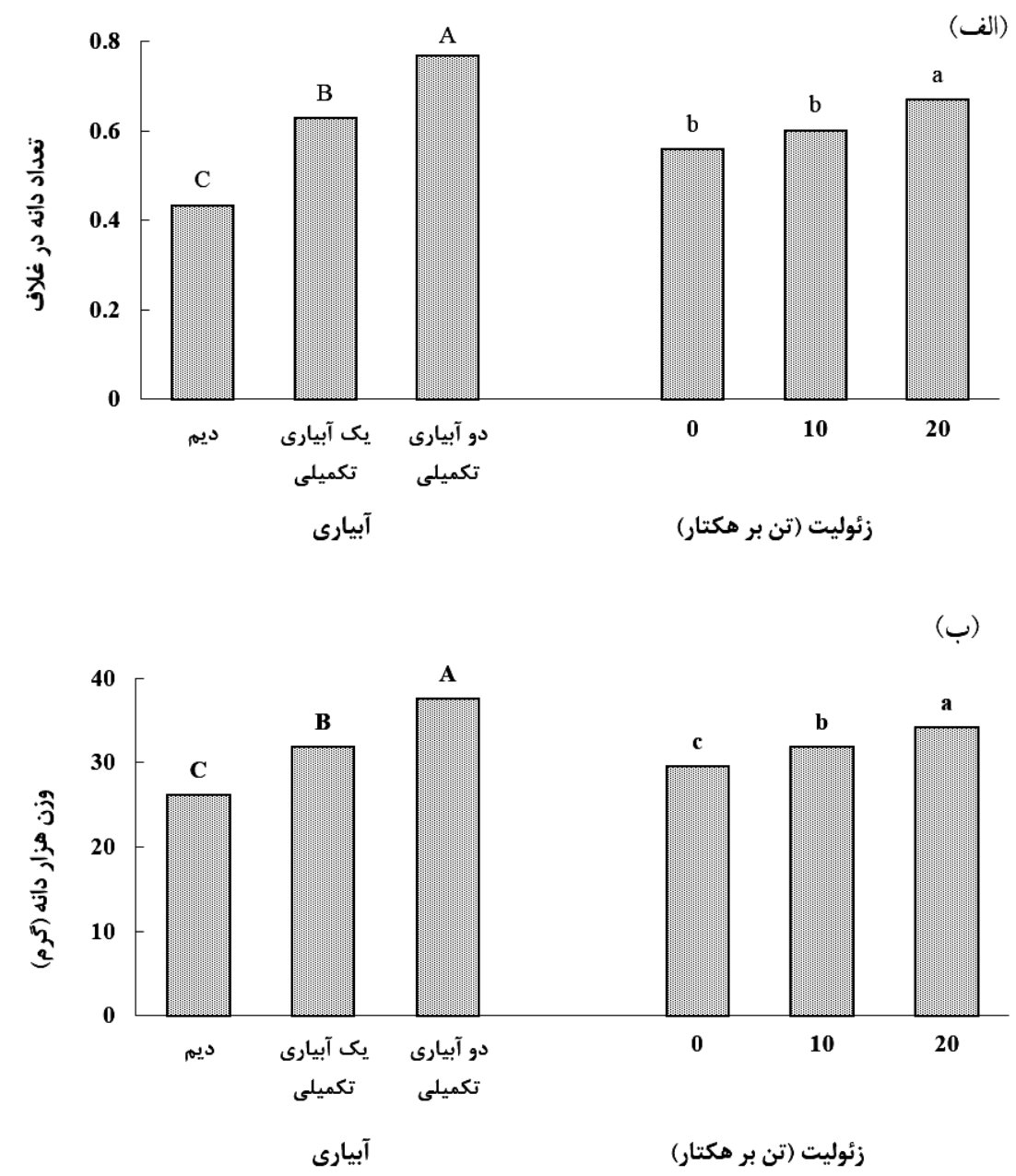

شكل F. اثر آبياى تكميلى و زئوليت بر تعداد دانه در غلاف (الف) و وزن هزار دانه (ب) در عدس. ميانگينهاى داراى حروف مشترى با

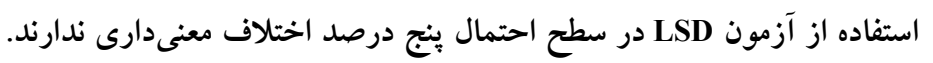

اثر معنى دارى در سطح احتمال يك درصد بر عملكرد دانه داشت.

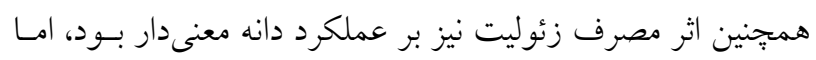

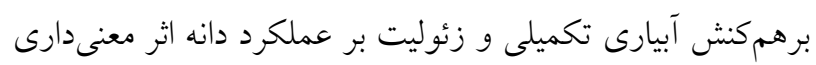

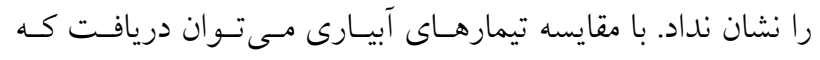

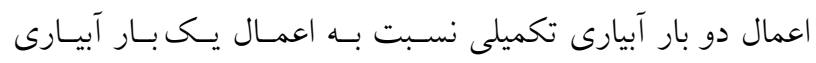

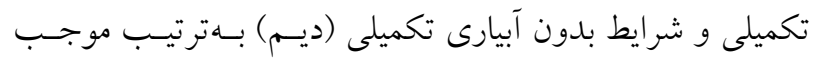

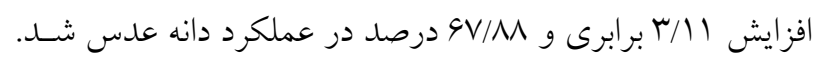

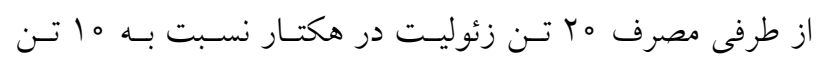

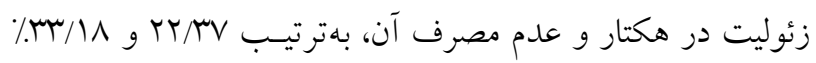

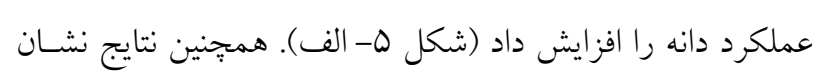

קروكيده و در نتيجه وزن هزار دانه كاهش مىيابد. نتـايج بـهدست

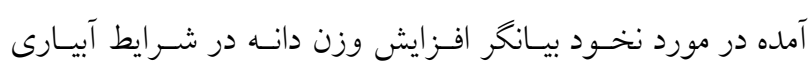

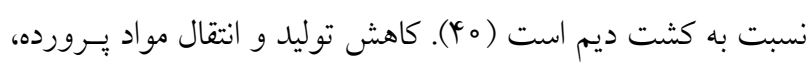

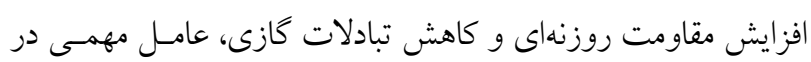
كاهش ظرفيت فتوستنزى در شرايط كم آبى است. در نتيجـهـ انتقـال

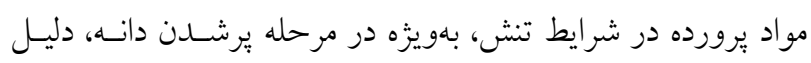
كاهش وزن هزار دانه در شرايط بروز تنش بوده است (ه).

عملكرد دانه همانطور كه در جدول r مشاهده مىشود، اعمال آبيارى تكميلى 

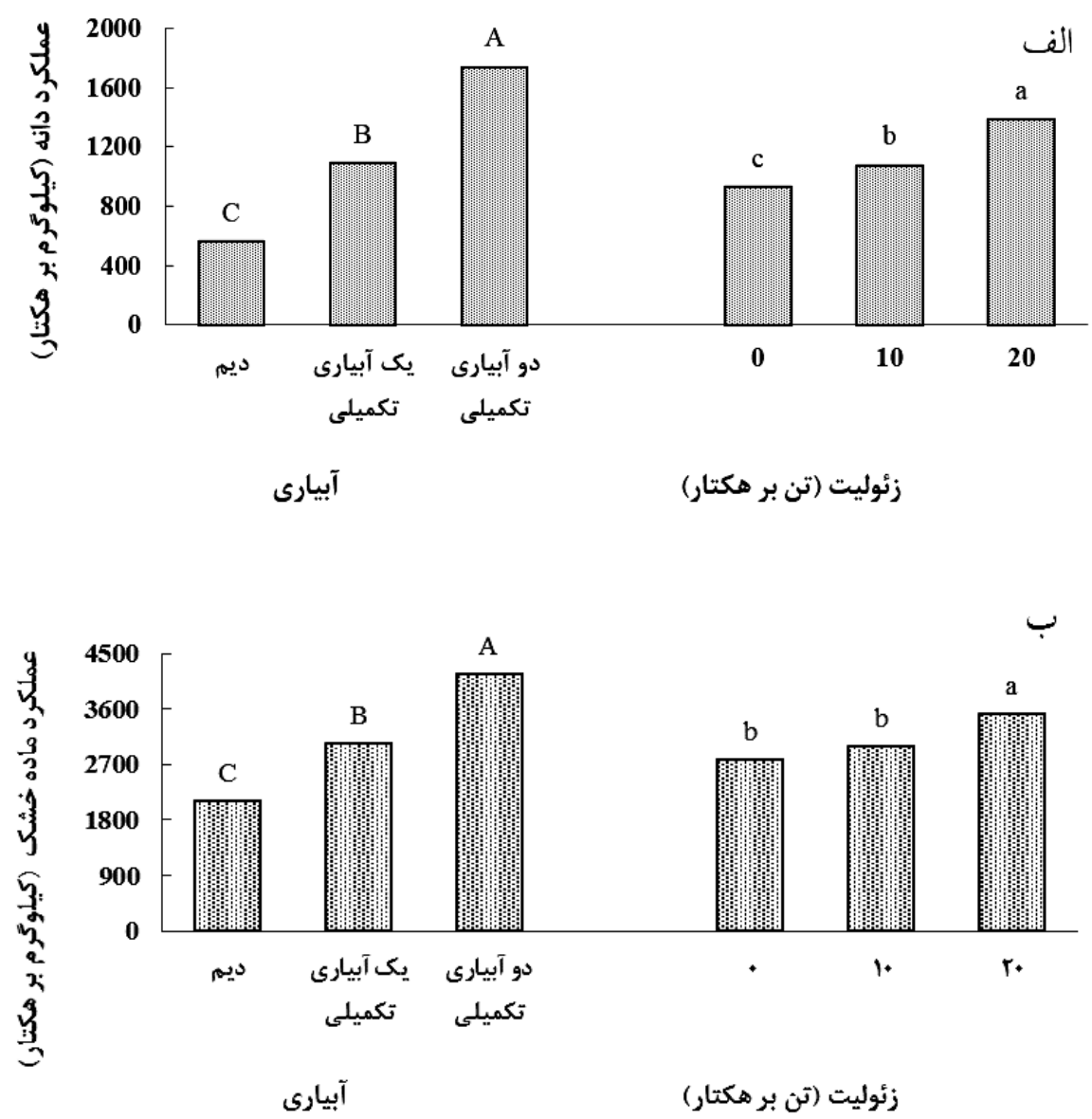

شكل ه. اثر آبياى تكميلى و زئوليت بر عملكرد دانه (الف) و عملكرد ماده خشك (ب) در عدس. ميانگينهاى داراى حروف مشترى با استفاده

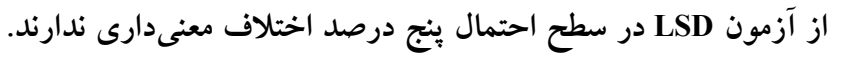

نور و دى اكسيد كربن بوده است را از دلايـل توليـــ بـالاتر مـاده خشك و در نهايت عملكرد دانه بيشتر دانستند، به عبـارت ديخـر،

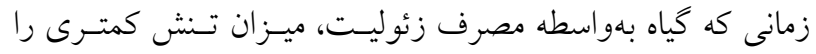

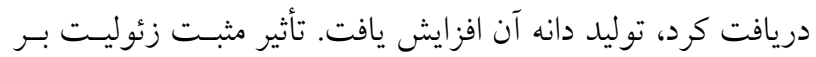

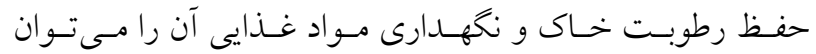

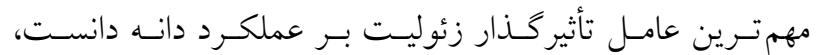
بهوطوى كه در مطالعهاى كزارش شد اثر زئوليت بر عملكرد دانسه

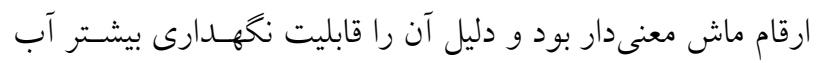

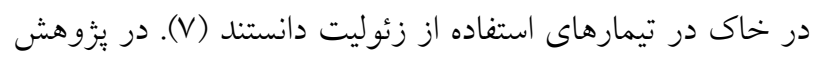

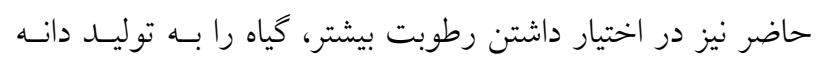

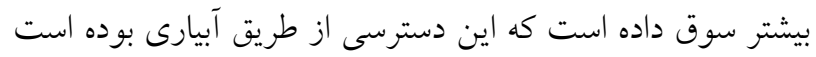

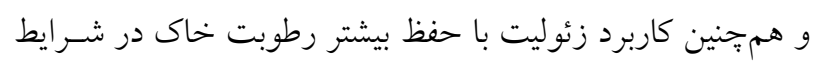

داد كه بيشترين عملكــد دانسه در تيمـار دو بـار آبيـارى تكميلى

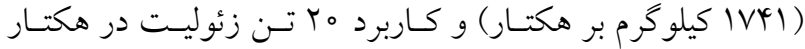

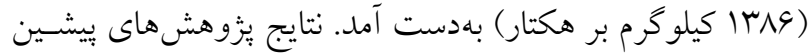
نشان داد كه در شرايط ديم، انجام آبيارى تكميلسى در هـر يـك از

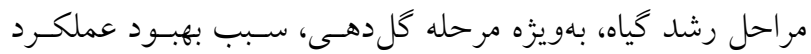

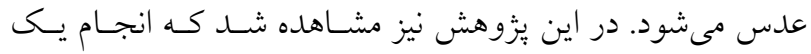

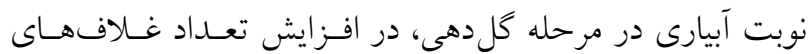
بارور و در نهايت عملكرد عدس مؤثر بوده است (T9). بالا بـودن

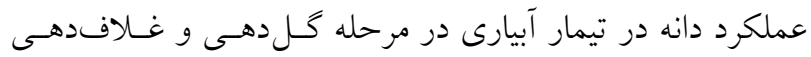

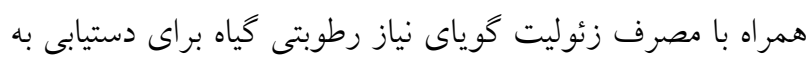

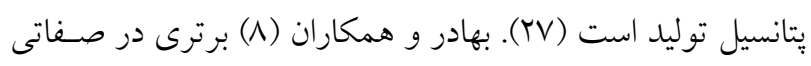

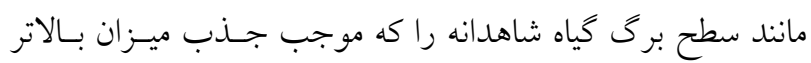


(19). يوراسماعيل و همكاران (1) با انجـام آزمايشى روى ارقـام

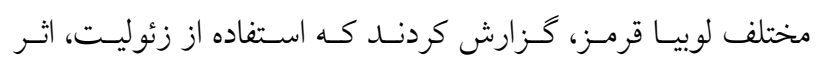

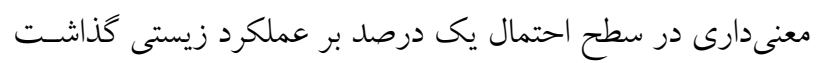
و اين صفت را افزايش داد.

\section{شاخص برداشت}

نتايج نشـان داد كـه اثـــ آبيـارى تكميلسى و مصـرف زئوليـت بـر

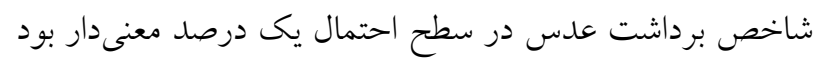

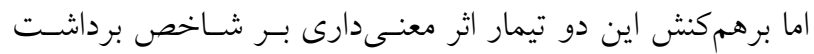

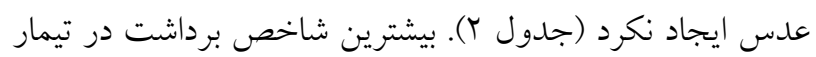
دو بار آبيارى تكميلى (الب درصد) مشاهده شـد. اعمـال دو بـار و

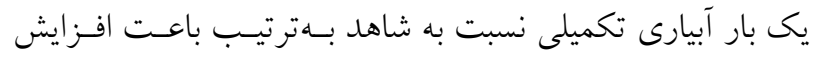

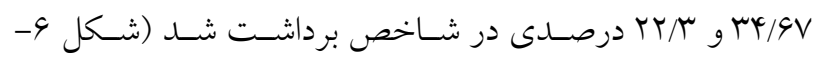

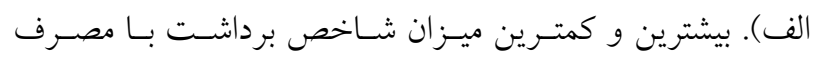

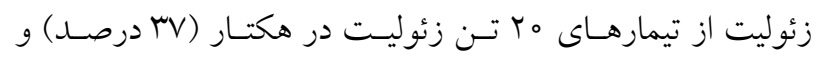

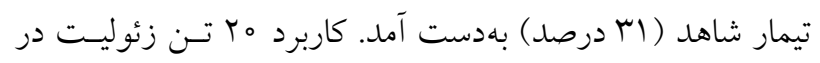

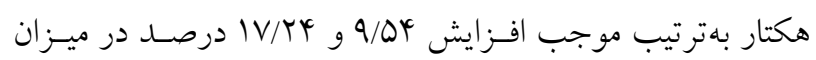

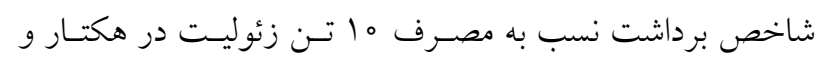

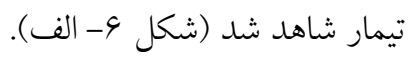
شاخص برداشـت كـه حاصـل نسـبت عملكـرد اقتصـادى بـهـ

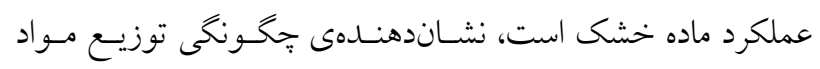
فتوستزى در انــامهـاى مختلـف كيـاه اسـت. شـاخص برداشـت

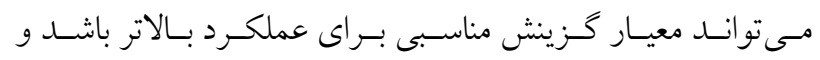

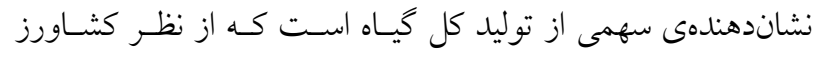

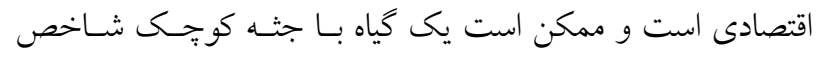

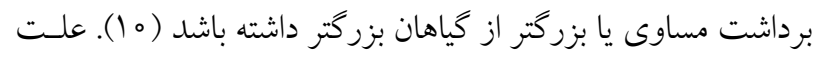

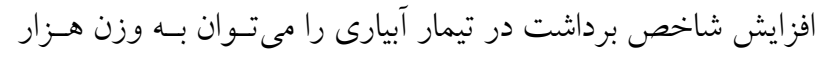
دانه بيشتر، تعداد دانه در غلاف بيشتر و تعداد بيشتر غلاف در بوتسه

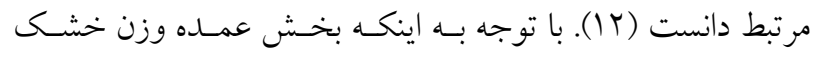

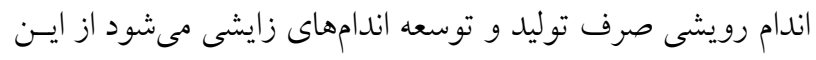
رو، كاهش فراهمى آب در دوره رويشى باعث كـاهش توليــ مـاده

خشك و متعاقبا كاهش دانه و شاخص برداشت مى درود (11).
محدوديت آبى، به بهبـود شـرايط آبـى كيـاه و افز ايش عملكـرد

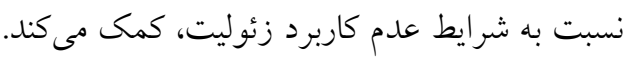

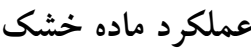

نتايج نشان داد كه اثر آبيارى تكميلسى و زئوليـت در سـطح احتمـال

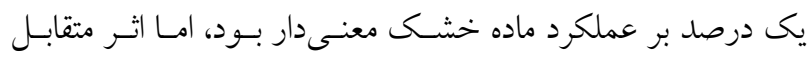

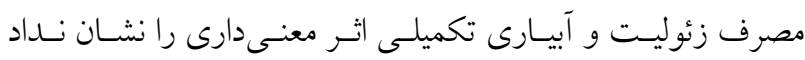

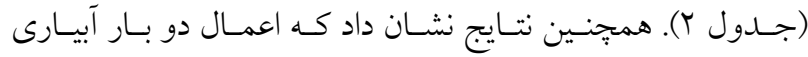
تكميلى باعث افزايش تقريبا دو برابرى ماده خشك نسبت به تيمـار

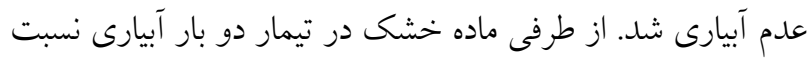

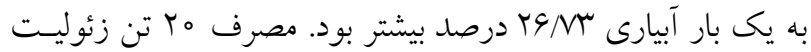

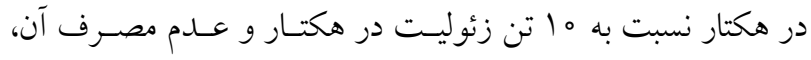

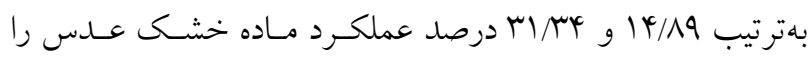

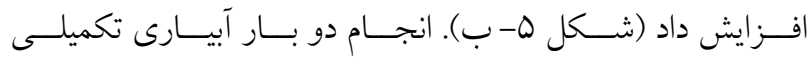

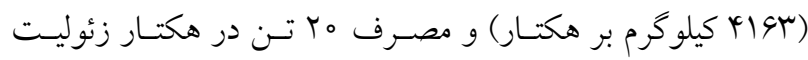

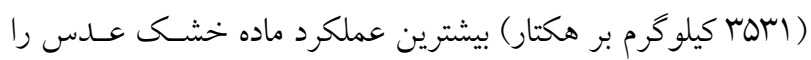

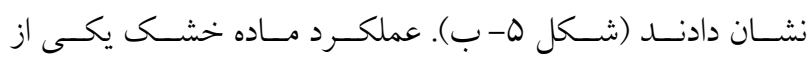

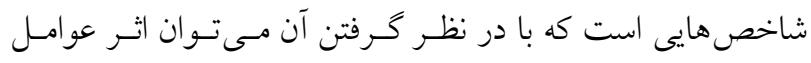

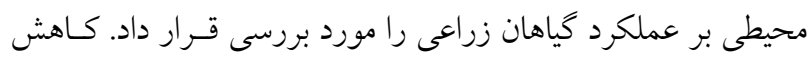

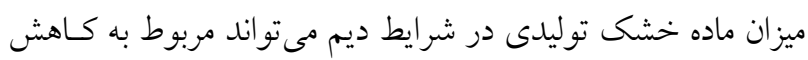

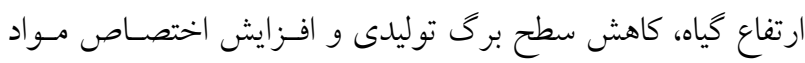

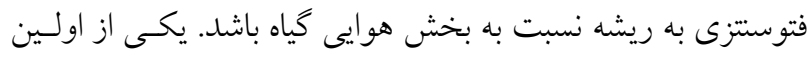

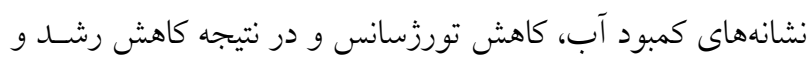

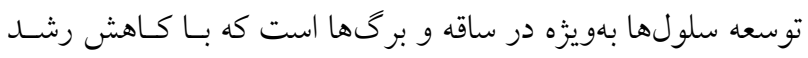
سلول، اندازه اندامها محدود مى شود و بههمين دليل است كه اولـين

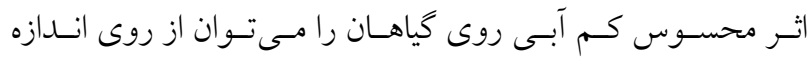

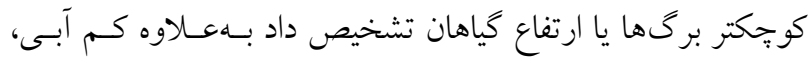
جذب مواد و عناصر غذايى را نيـز كـاهش داده و بنـابراين توسـعه

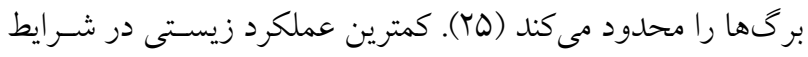
كاربرد زئوليت از تيمار شاهد گزارش شد كه با نتايج ديخر محققـان

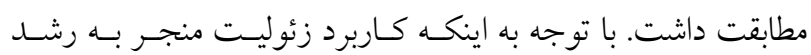

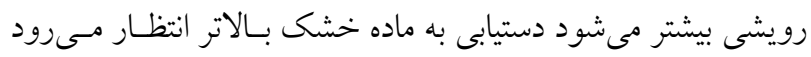



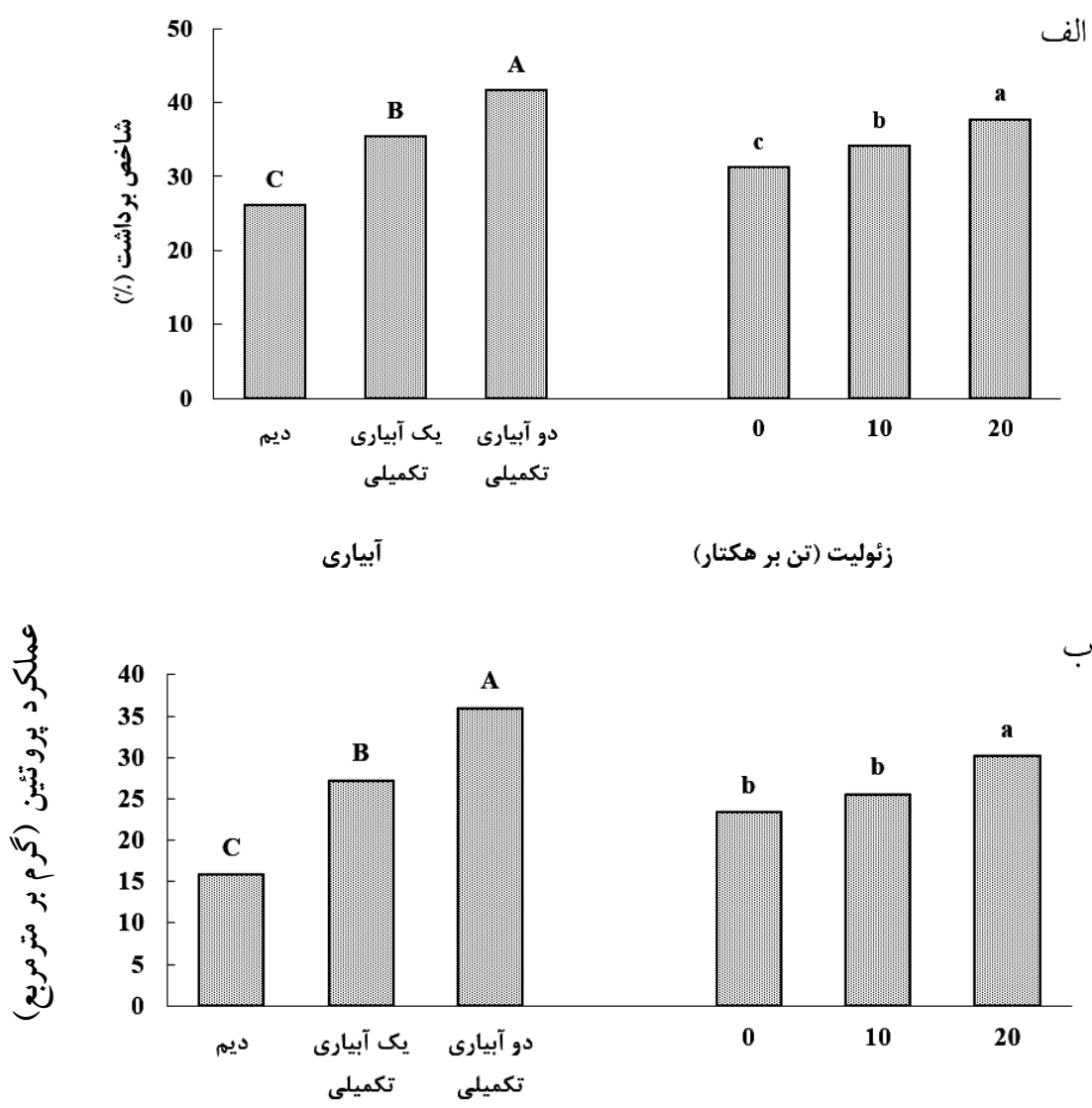

آبيارى

رئوليت (تن بر هكتار)

شكل و. اثر آبياى تكميلى و زئوليت بر شاخص برداشت (الف) و عملكرد بروتئين (ب) در عدس. ميانگين هاى داراى حروف مشترى با استفاده از آزمون LSD در سطح احتمال بينج درصد اختلاف معنى دردارى ندارند.

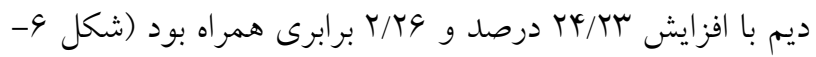

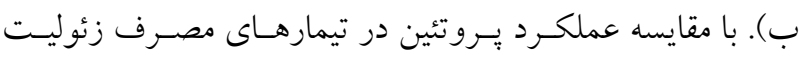
عملكرد بروتئين

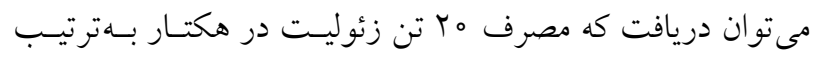

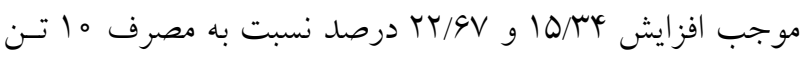

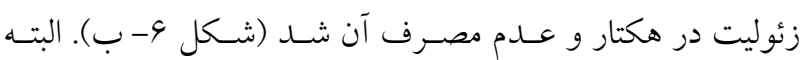

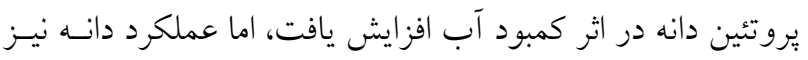

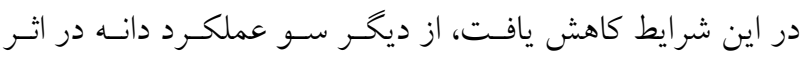

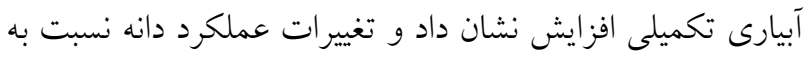

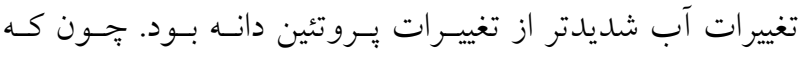

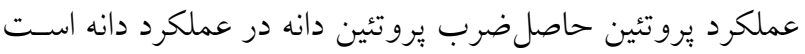
در نهايت بيشترين عملكـرد يـروتئين در شـرايط دو بـار آبيـارى

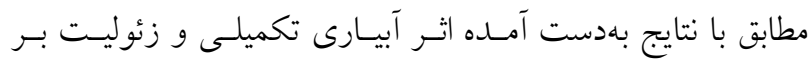

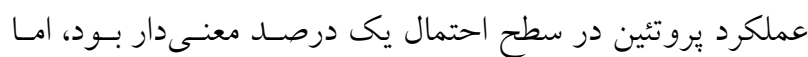

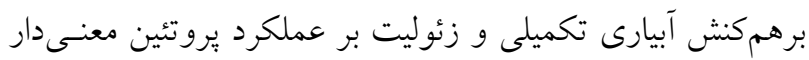

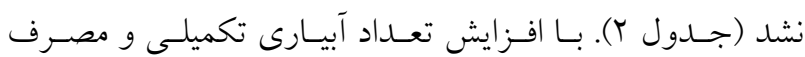
زئوليت بر عملكرد يروتئين افزوده شـا، بـهــورى كسه بيشترين

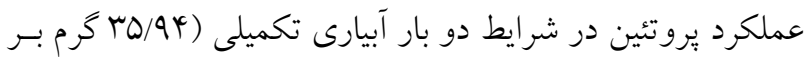

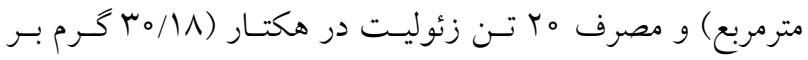

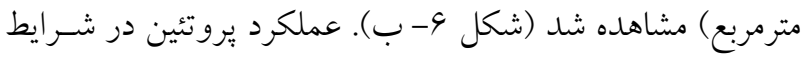
دو بار آبيارى تكميلى نسبت به يك بار آبيارى تكميلس و شـرايط 


$$
\begin{aligned}
& \text { تكميلى بلهست آمد. كودهـاى زئوليـت بـهدليـل اخـتلاف فشـار و زئوليت سبب بهبود سرعت رشد گياه و شاخص سـطح بـرى } \\
& \text { اسمزى، خاصيت تبادل كاتيونى و ايجاد تعادل با محسيط اطـراف، در كياه عدس مىشوند. همجنين صفات مرتبط با عملكـرد نيـز }
\end{aligned}
$$

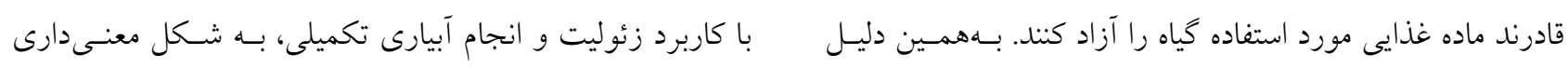

$$
\begin{aligned}
& \text { به آنها كود هوشمند مى گويند (مب). زئوليتها بـا افز ايش اتـرات بهبود يافتند. بهطور كلى با توجه به نتايج بـهدسـت آمـده، لـزوم } \\
& \text { كودهاى شيميايى همانند يك كود كند رها شونده در خـاك عمـل تكرار آزمايش مشـابه در منطقـه شهركرد در سـالهـاى ديخـر، } \\
& \text { مى كنند كه نخهارى رطوبـت در خـاك را بهبـود داده و بـهدليـل تصميم گيرى در كاربرد نقش زئوليت در كشت ديم را (با وجود }
\end{aligned}
$$

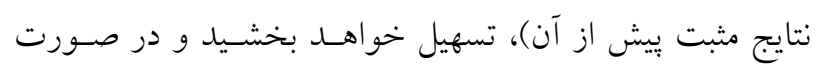

$$
\begin{aligned}
& \text { ثبت نتايج مثبت در آزمايش هاى آتى، مىتـوان شـرايط خشـى } \\
& \text { رخ داده در كل كشور بهويزه ديسمزارهـا را بـا كـاربرد زئوليـت } \\
& \text { اميدبخش نخه داشت. } \\
& \text { تخلخل مناسب به تهويه خاى كمك مى كنند (1). } \\
& \text { تتيجه كيرى كلى }
\end{aligned}
$$

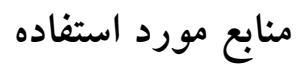

1. Abdi, G. H., M. Khosh Khui and S. Eshghi. 2006. Effects on natural zeolite on growth and flowering on strawberry. International Journal of Agricultural Research 1: 384-389.

2. Ahmadpour, R. and S. R. Hoseinzade. 2017. Evaluation of the effects of water stress and municipal waste compost fertilizer on morphophysiological indices and yield components of lentil. Journal of Plant Environmental Physiology 46: 42-56. (In Farsi).

3. Antolin, M. C. and M. Sanchez-Diaz. 1993. Effects of temporary droughts on photosynthesis of alfalfa plants. Journal of Experimental Botany 44(8): 1341-1349.

4. Bagheri, A., M. Goldani and M. Hassanzadeh. 1997. Cultivation and Breeding of Lentils. Ferdowsi University of Mashhad, Mashhad.

5. Bahador, M. and M. R. Taddoyon. 2018. Effect of deficit irrigation and zeolite levels on phenology, oil yield and water use efficiency of hemp. Iranian Journal of Field Crop Science 49(3): 25-38. (In Farsi).

6. Bahador, M. and M. R. Taddoyon. 2020. Investigating of zeolite role in modifying the effect of drought stress in hemp: Antioxidant enzymes and oil content. Industrial Crops and Products 144: 112042.

7. Bahador, M., A. R. Abdali Mashhadi, A. Siadat, Gh. Fathi and A. Lotfi Jalal-Abadi. 2015. Effect of Zeolite and seed priming on grain nitrogen content, leaf chlorophyll and traits dependent to grain yield of Mung bean (Vigna radiate L.) cultivars. Journal of Plant Process and Function 4(11): 137-147. (In Farsi).

8. Bahador, M., M. R. Taddayon, M. Rafi Alhoseini and M. H. Salehi. 2017. Changes of canopy temperature and some physiological traits of hemp (Cannabis sativa) under deficit water stress and zeolite rates. Environmental stresses in agricultural sciences 10(2): 269-279. (In Farsi).

9. Bremner, J. M. and C. S. Mulvaney. 1982. Methods of soil analysis. Part 2. Chemical and microbiological properties. pp. 595-624, In: A. L. Page, R. H. Miller and D. R. Keeney (Eds.), American Society of Agronomy. Soil Science Society of America. Madison, Wisconsin.

10. Campbell, C. A., R. P. Zentner, F. Selles, V. O. Biederbeck and A. J. Leyshon. 1992. Comparative effects of grain lentil-wheat and monoculture wheat on crop production, $\mathrm{N}$ economy and $\mathrm{N}$ fertility in a Brown Chernozem. Canadian Journal of Plant Science 72: 1091-1107.

11. Clavel, D., N. K. Drame, H. Roy-Macauley, S. Braconnier and D. Laffray. 2005. Analysis of early responses to drought associated with field drought adaptation in four Sahelian groundnut (Arachis hypogaea L.) cultivars. Environmental and Experimental Botany 54: 219-230.

12. De Costa, W. A. and K. N. Shanmugathasan. 1999. Effects of irrigation at different growth stages and source-sink manipulations on yield and yield Components of Mung Bean, Vigna radiata (L.) Wilczek, in Dry and intermediate zones of Sri Lanka. Journal of Agronomy and Crop Science 183(2): 111-117.

13. Erskine, W., F. J. Muehlbauer and R. W. Short. 1990. Stages of development in lentil. Experimental Agriculture 26: 297-302. 
14. Ghazavi, R. 2015. The application effects of natural zeolite on soil runoff, soil drainage and some chemical soil properties in arid land area. International Journal of Innovation and Applied Studies 13: 172-177.

15. Gholamhoseini, M., M. AghaAlikhani, A. Dolatabadian, A. Khodaei-Joghan and H. Zakikhani. 2012. Decreasing nitrogen leaching and increasing canola forage yield in a sandy soil by application of natural zeolite. Agronomy Journal 104(5): 1467-1475.

16. Habib Porkashefi, E., M. H. Gharineh, A. R. Shafeinia and M. Roozrokh. 2017. Effect of different levels of zeolite on yield of red bean (Phasaeolus vulgaris L.) under drought stress in Kermanshah climate condition. Crop Production Technology 17(1): 141-151. (In Farsi).

17. He, Z. L., D. V. Calvert, A. K. Alva, Y. C. Li and D. J. Banks. 2002. Clinoptilolite zeolite and cellulose amendments to reduce ammonia volatilization in a calcareous sandy soil. Plant and Soil 247: 253-260.

18. Hosseini, F. S., A. Nezami, M. Parsa and K. Hajmohammadnia Ghalibaf. 2011. Effects of supplementary irrigation on yield and yield components of lentil (Lens culinaris Medik.) cultivars in Mashhad climate. Journal of Water and Soil 25(3): 625-633. (In Farsi).

19. Ippolito, A. J., D. D. Tarkalson and G. A. Lehrsch. 2011. Zeolite soil application method affects inorganic nitrogen, moisture, and corn growth. Soil Science 176(3): 136-142.

20. Karim, M. F. and Q. A. Fattah. 2007. Growth analysis of chickpea cv. Bari Chhola-6 as affected by foliar spray of growth regulators. Bangladesh Journal of Botany 36(2): 105-110.

21. Karimzadeh Soureshjani, H. A., M. R. Tadayon, M. Shalalvand and Y. Fardi. 2019. Evaluation of growth indices and qualitative traits of maize hybrids at different sowing dates in Varamin, Iran. Journal of Crop Production and Processing 8(4): 29-44. (In Farsi).

22. Kayan, N. 2008. Variation for yield components in two winter sown lentil cultivars (Lens culinaris Medic.). Bulgarian Journal of Agricultural Science 14(5): 460-465.

23. Khan, H., A. Z. Khan, R. Khan, N. Matsue and T. Henmi. 2008. Zeolite application affects vegetative phenology of determinate and indeterminate soybean grown on allophanic soil. International Journal of Agricultural Research 3(2): 148-154.

24. Maleki, S., A. Nakhzari moghaddam, S. H. Sabbaghpoor, A. Noorinia and H. Sabouri. 2018. Investigation of the effect of zeolite and potassium application on some traits and yield of chickpea (Cicer arietinum L.) in different irrigation managements. Iranian Journal of Pulses Research 9(2): 114-125. (In Farsi).

25. Mandal, B. K., P. K. Ray and S. Dasgupta. 1986. Water use by wheat, chickpea and mustard grown as sole crops and intercrops. Indian Journal of Agricultural Sciences 56: 187-193.

26. Millan, N. G., F. Agosto, M. Va'zquez, L. Botto, L. Lombardi and L. Juan. 2008. Use of clinoptilolite as a carrier for nitrogen fertilizers in soils of the Pampean regions of Argentina. Ciencia e Investigacio'n Agraria 35: $245-254$.

27. Naseri, R., M. J. Rahimi, S. A. Siyadat and A. Mirzaei. 2015. The effects of supplementary irrigation and different plant densities on morphological traits, yield and its components and protein content of chickpea (Cicer arietinum L.) in Sirvan region in Ilam province. Iranian Journal of Pulses Research 6(1): 78-91. (In Farsi).

28. Oweis, T. and A. Hachum. 2006. Water harvesting and supplemental irrigation for improved water productivity of dry farming systems in west Asia and north Africa. Agricultural Water Management 80: 57-73.

29. Oweis, T., A. Hachum and M. Pala. 2005. Lentil production under supplemental irrigation in a Mediterranean environment. Agricultural Water Management 68: 251-265.

30. Polat, E., M. Karaca, H. Demir and A. Naci Onus. 2004. Use of natural zeolite (clinoptilolite) in agriculture. Journal of Fruit Ornamental Plant Research 12: 183-189.

31. Pooresmail, P., D. Habibi, A. Tavasoli, M. Mashhadi Akbari Booojar, B. Roshan and H. Rafiei. 2009. Evaluation of the effect of water superabsorbent polymer on yield improvement and yield components of different red bean cultivars under drought stress. Iranian Journal of Agricultural Science 4(3): 310-379. (In Farsi).

32. Rahimi, M. 2009. The effect of zeolite on optimal nitrogen consumption in rapeseed cultivation, MSc Thesis. Islamic Azad University. Miyaneh Branch, Iran. (In Farsi).

33. Rahimi, M. M. and Gh. Noormohammadi. 2010. Effects of sowing time and different nitrogen levels on quantitative and qualitative charecteristics of oil flax (Linum usitatissimum L.). Seed and Plant Production 25(1): 79-91.

34. Russelle, M. P., W. W. Wilhelm, R. A. Olson and J. F. Power. 1984. Growth analysis based on degree days. Crop Science 24: 28-32.

35. SAS, I. 2007. SAS User's Guide in Statistics. SAS Institute. Inc., Cary.

36. Shadroo, V., A. M. Shirani Rad and M. Yoosefi. 2011. Effect of different irrigation regimes on yield and yield components of three barley cultivars in zeolite treatment. In: National Conference on New Achievements in Agriculture. Young Researchers Club of Shahr-e-Quds Branch, Iran. (In Farsi). 
37. Singh, S. P. 1995. Selection for water stress tolerance in interracial populations of common bean. Crop Science 35 : 118-128.

38. Tesfaye, K., S. Walker and M. Tsubo. 2006. Radiation interception and radiation use efficiency of three grain legumes under water deficit conditions in a semi-arid environment. European Journal of Agronomy 25: 60-70.

39. Tuba Bicer, B., A. Narin Kolender and D. A. Akar. 2004. The effect of irrigation on spring-sown chickpea. Journal of Agronomy, Asian Network for Scientific Information 3: 154-158.

40. Ullah, A., J. Bakht, M. Shafi, W. A. Shah and Z. Islam. 2002. Effect of various irrigations level on different chickpea varieties. Asian Journal of Plant Science 1: 355-357.

41. Virta, R. L. 2008. Mineral resource of the month: natural and synthetic zeolites. Geotimes 53(6).

42. Zamani Noori, A., A. Ghashghayi and S. Hoseini Abri. 2013. Effect of zeolite on yield, yield components and bean protein. In: The first national conference on sustainable agricultural development using the agricultural model. 24 February. Hamedan, Iran. (In Farsi). 


\title{
Effect of Supplementary Irrigation and Application of Zeolite on the Growth and Yield of Lentils (Lens culinaris Medik) under Rainfed Conditions
}

\author{
M. Ghashghaei ${ }^{1}$, M.R. Tadayon ${ }^{2}$, M. Bahador ${ }^{3}$ and H. Karimzadeh ${ }^{4}$
}

(Received: May 09-2021; Accepted: July 31-2021)

\begin{abstract}
In order to investigate the effect of zeolite on growth indices, yield and grain yield components and protein of lentil in dryland and supplementary irrigation conditions, a field study was conducted in Shahrekord University, Shahrekord, Iran. The experiment was performed as a split plot in a randomized complete block design with three replications. The main factor included three levels of irrigation (rainfed, one stage of supplementary irrigation and two stages of supplementary irrigation) and the second factor included the application of three levels of zeolite (0,10 and 20 tons ha $^{-}$ $\left.{ }^{1}\right)$. The results showed that supplementary irrigation increased the grain yield. Application of zeolite moderated the effect of drought stress. Zeolite improved grain yield, this improvement occurred under both supplementary irrigation and rainfed conditions. Though, the interaction of supplementary irrigation and zeolite on yield and yield components was not statistically significant. Supplementary irrigation and zeolite had a significant effect on growth indices and improved growth indices during the growing season. The highest grain yield $\left(1741 \mathrm{~kg} \mathrm{ha}^{-1}\right)$ was obtained when supplementary irrigation was applied at two stages. Application of 20 tons ha ${ }^{-1}$ of zeolite increased grain yield by $50 \%$ compared to the control. Therefore, according to the findings of the present study, in conditions of water restriction, application of 20 tons $\mathrm{ha}^{-1}$ of zeolite may benefit lentil cultivation in Shahrekord, Iran.
\end{abstract}

Keywords: Drought stress, Growth indices, Pulses, Rainfed conditions

1, 2 and 3. MSc Student, Professor and Former PhD Students, Respectively, Agronomy Department, Shahrekord University, Shahrekord, Iran.

4. Postdoctoral Researcher, Research Center for Plant Science, Ferdowsi University of Mashhad, Mashhad, Iran

*: Corresponding Author, Email: mrtadayon@yahoo.com 